Law \& Economics Working Papers

Law \& Economics Working Papers Archive:

2003-2009

University of Michigan Law School

Year 2005

\title{
The Deregulation of International Trucking in the European Union: Form and Effect
}

\author{
Francine Lafontaine* $^{*} \quad$ Laura M. Valeri ${ }^{\dagger}$
}

*University of Michigan Law School, laf@umich.edu

$\dagger$ University of Michigan Law School, lauramv@umich.edu

This paper is posted at University of Michigan Law School Scholarship Repository.

http://repository.law.umich.edu/law_econ_archive/art51 


\title{
UNIVERSITY OF MICHIGAN
}

JOHN M. OLIN CENTER FOR LAW \& ECONOMICS

\author{
THE DEREGULATION OF \\ INTERNATIONAL TRUCKING \\ IN THE EUROPEAN UNION: \\ FORM AND EFFECT
}

FRANCINE LAFONTAINE

AND LAURA M. VALERI

PAPER \#05-006

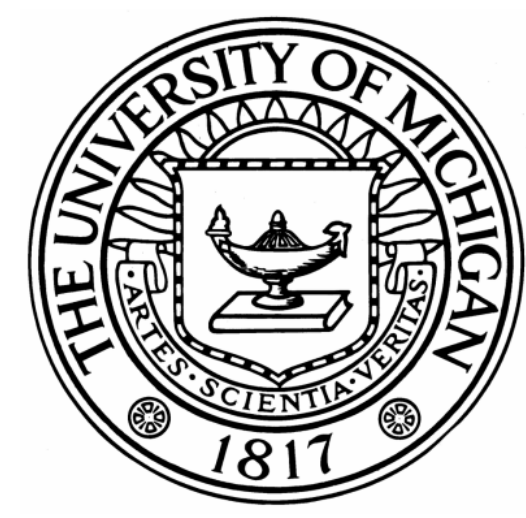

THIS PAPER CAN BE DOWNLOADED WITHOUT CHARGE AT:

Michigan John M. Olin Website

HTTP://WWW.LAW.UMICH.EDU/CENTERSANDPROGRAMS/OLIN/PAPERS.HTM 


\title{
The Deregulation of International Trucking in the European Union: Form and Effect
}

\author{
Francine Lafontaine \\ laf@umich.edu \\ and \\ Laura Malaguzzi Valeri* \\ lauramv@umich.edu
}

April 25, 2005

\begin{abstract}
This paper examines how the deregulation of the international road transport industry in Western Europe has affected 1- the total quantity of cross-border road transport in the region; 2- the degree to which shippers outsource rather than integrate vertically their cross-border transport needs; and 3- the extent to which different countries participate in international road freight transport in Western Europe. Not surprisingly, we find that deregulation has had a large positive effect on the amount of international road transport net of the effect of the trade ties that grew over time among European Union countries. Moreover, consistent with the fact that the regulation disproportionately affected for-hire trucking, we find that deregulation has led shippers to shift toward more for-hire transport as opposed to own-account or private haulage. However, despite concerns voiced by member countries, we find no evidence that deregulation has disproportionately favored carriers of countries that were initially more (or less) intensively involved in international haulage.
\end{abstract}

\footnotetext{
${ }^{*}$ Professor of Business Economics and Public Policy, Ross School of Business, University of Michigan, and Ph.D. Candidate, Dept. of Economics, University of Michigan, respectively. This research was supported in part by the Sloan Foundation via the University of Michigan Trucking Industry Program, and by the Pre-dissertation Fellowship in Applied Economics, awarded by the Social Science Research Council. We thank John Allen of Eurostat, in Luxembourg, who provided office space at Eurostat and several contacts. The usual caveat applies.
} 


\section{Introduction}

The deregulation of the interstate trucking industry took place, in the USA, with the Motor Carrier Act of 1980, which removed entry barriers and eliminated price-setting bureaus. A number of studies have established how this deregulation has led to lower transport prices, changes in the organization of labor, and changes in the concentration and organization of the industry (e.g. Rose 1985 and 1987, Joskow and Rose, 1989, Winston et al., 1990, Ying and Keeler, 1991, Boyer 1993, Peoples and Peteraf, 1995 and 1999).

At that same time, in the European Union, ${ }^{1}$ a complex series of bilateral and multilateral agreements still governed both the amount of road transport that could be done between countries and the prices that could be charged for such transport. ${ }^{2}$ This was the case despite the fact that the 1957 Treaty of Rome establishing the European Economic Community stated that a common transport policy had to be achieved by December 1969. In fact, the deregulation of international road transport in the European Union did not begin until the mid-1980s. Moreover it was much more gradual than in the USA, having been completed, or at least mostly completed, only at the end of the 1990s. Finally, the stated reasons to deregulate international transport in the European Union, and some of the concerns surrounding such deregulation, were different from those associated with U.S. deregulation. In particular, instead of emphasizing potential efficiency gains, an important motivation for deregulation in the European Union was the desire to eliminate government discrimination based on nationality of the freight transport provider. Not surprisingly, individual member countries thus worried about potential market share losses

\footnotetext{
${ }^{1}$ Prior to 1992 the European Union (EU) was the European Communities, the most important of which was the European Economic Community (EEC).

${ }^{2}$ In this study we focus exclusively on international road freight transport as it functions under its own set of rules and is the type of haulage affected by the supranational European Union rules. Individual national trucking markets within the EU also have historically been regulated and have gone through their own deregulation processes.
} 
in deregulated sectors. These differences in stated goals and concerns, in turn, affected the form and speed of the deregulation process.

Due in part to timing and duration of the deregulation, and in part to data issues discussed below, the effects of deregulation of the trucking industry in the European Union (EU from now on) have not received much attention in the literature. ${ }^{3}$ This paper begins to fill that gap by describing in some detail the process of deregulation that occurred in the EU in the 1980s and 1990s, and then analyzing how it has affected 1- the total amount of international road transport, 2- the extent to which shippers outsource their transport needs, and 3- the degree to which countries participate in international road transport. In the USA, studies have explicitly focused on the effect of deregulation on pricing. Unfortunately, data limitations prevent us from doing the same. However, our finding that the relaxation of regulations has had a large positive effect on the total amount of international road transport, beyond what would be expected due to the increased trade among EU countries, suggests that relative to alternative modes of transportation, the cost to shippers of relying on road transport have gone down over time as a result of deregulation. In other words, this result is consistent with the lower road transport prices one would associate with deregulation. Contrary to the U.S., where authors have found no evidence of change in the extent of private versus for-hire road transport resulting from deregulation, we find that deregulation has reduced the tendency of shippers to own and operate their own trucks for international transport in the EU. Instead shippers there have turned to firms that specialize in freight transport for their shipping needs. This finding suggests that deregulation has reduced the cost of for-hire trucking relative to own account haulage, a finding that is consistent with our expectations given that the for-hire segment was much more highly regulated than own-account

\footnotetext{
${ }^{3}$ Existing studies on European deregulation of trucking include OECD (1988, 1990), Allen (1990), ECMT (1991, 2002), , McKinnon (1996), European Commission (1997) and Fernandez et al. (2000). Boylaud (2000) summarizes the results of several empirical studies on road freight transportation deregulation worldwide.
} 
haulage was. Finally, despite concerns to this effect, we find no evidence that deregulation has affected the degree to which different countries participate or specialize in road transport. Carriers of any given country as a group were not disproportionately better or worse off after deregulation.

The paper is organized as follows. First, we review the general characteristics of the road transport market in Europe and how it compares to the USA in the next section. We then describe how the European international trucking industry was regulated and the process of deregulation in section 3 . We present hypotheses concerning the likely effects of deregulation in section 4. Section 5 describes the data that we rely on, while section 6 contains the empirical model and results. Concluding remarks are found in section 7.

\section{The trucking industry in Europe}

The European Union is different from the USA in many ways, some of which are admittedly very obvious, but some can usefully be restated. First of all the EU is an association of individual countries that do not share a common language, common taxes or common business environments. The European Union is a supranational power that oversees international transport while each country retains jurisdiction over its own domestic transport (as long as its policies do not discriminate by nationality of the carrier). As a result national and international markets obey rules that can be very different. In this paper, we focus explicitly on international or cross-border - road transport.

In 2001, road transport accounted for $45 \%$ of all freight transported among the $15 \mathrm{EU}$ member states, measured in ton-kilometers $(\mathrm{t}-\mathrm{kms}){ }^{4}$ Another $7.8 \%$ was transported by rail, $4 \%$ by inland waterways, $2.8 \%$ through pipelines and $40.4 \%$ by sea. Excluding sea shipping, road

\footnotetext{
${ }^{4}$ A ton-kilometer represents one ton $(1000 \mathrm{~kg})$ of freight transported for one $\mathrm{km}$.
} 
freight haulage is by far the dominant transport mode, with $75.5 \%$ of the total $\mathrm{t}$-kms. This fraction also has grown significantly since 1980 when it was $60 \%$ (EU, 2003). By comparison, within the USA, where geography rules out sea shipping, $32.2 \%$ of total $\mathrm{t}-\mathrm{kms}$ were transported by road in 2000 , while $41.3 \%$ went by rail, $10.2 \%$ by inland waterways, and $16.3 \%$ through pipelines. The much higher reliance on rail in the USA reflects the fact that railways are used primarily for long-distance and heavy freight transport. $^{5}$

Broadly speaking, two types of firms are involved in road transport: motor carriers, who operate in the for-hire sector, providing service in exchange for compensation from shippers, and shippers themselves who rely on their own resources to transport their own goods. Together, the latter form what is usually called the private or own-account trucking segment. ${ }^{6}$ In 1998 , the forhire trucking industry accounted for $4 \%$ of GDP in Europe. Private haulage (own account) added another $1 \%$, so that on the whole the industry accounted for $5 \%$ of total GDP (EU, 2000). Trucking also accounts for about 5\% of GDP in the USA. The split between own-account and for-hire is quite different, however, with the own-account sector in the USA taking up about 50\% of total t-kms (Hubbard, 1998).

In the European Union, about $30 \%$ of national road transport (i.e. within country) t-kms are transported via own-account haulage. This falls to $10 \%$ for international - or cross-border haulage. For large countries such as France, international road freight transport is a fairly small percentage of total freight transported by road (national + international), accounting for about $14 \%$ in 1982 and growing to $20 \%$ by the end of the 1990 s. For smaller countries, which also tend to be more centrally located countries, such as Belgium, the percentage was as high as $65 \%$

\footnotetext{
${ }^{5}$ In particular, when the shares are measured in terms of revenues rather than t-kms, the share of rail is much lower in the USA. Reliable data based on revenues are not available for Europe.

${ }^{6}$ In the USA, this is usually called private haulage while in Europe, it is more standard to refer to this as own account. In Europe, own-account transport was originally defined in the 1957 resolution of the ECMT (European Council of the Ministers of Transport). See Appendix A for details.
} 
at the beginning of the 1980 s and reached about $70 \%$ by 1998 . Not surprisingly, islands such as the UK and Ireland have a very small percentage of international road freight transport.

\section{Regulation and deregulation of international road transport in Europe}

To appreciate the basic characteristics of international road transport regulation and deregulation in Europe, it is useful to recognize that, as stated earlier, the EU has jurisdiction only over the international component of the European road transport market. Each country still can set its own rules for transport that begins and ends within its borders. Second, as in the USA, regulations in this market have been imposed on both entry and price. Not every European country regulated both the prices at which shipments could take place and the number of licenses that were available to carriers for international transport, but most of them did one or the other. Third, and lastly, during periods of heavy regulation the own-account sector was relatively unregulated. However now that the for-hire sector has been mostly liberalized, the continuing regulations on the own-account transport make it the most regulated segment of the industry. Specifically, throughout the period covered by this study and to this day, transporters for ownaccount were not allowed to carry third-party freight generally, and for-hire backhauls specifically, defined as hauls that take the carrier back to the country of origin but that do not involve the carrier's own goods.

At the beginning of the 1980s, for-hire road haulage between EU member states was authorized in one of four ways:

1. Under bilateral agreements between member states. These agreements either allowed free movement of goods or imposed quotas on the number of movements. If a journey involved transit through a third country, then a permit might be needed from that country 
as well. ${ }^{7}$ Under these bilateral agreements, the transport permit granted to a carrier could be limited to a certain period or a certain number of journeys. ${ }^{8}$ Bilateral agreements applied to both the for-hire and the own-account sector (Bernadet 1997 and Scharf and Smolders 1999) until 1980 (see point 2) and thereafter only to the for-hire sector. These permits were the norm for all international European transport (within and outside of the EU) until the late 1980s. From the mid 1990s onward, they were only needed for transport outside of the EU, and they have remained the norm for transport to and from Eastern European countries. Note that the European Union had only nominal control over bilateral agreements between member states. ${ }^{9}$

2. Under Community permits. These permits, or quota arrangements, were instituted in 1969, and allowed a limited number of vehicles to operate freely within the Community. ${ }^{10}$ Each country was allocated a quota and decided how to distribute it among its national motor carriers. The permits allowed unlimited international journeys during one year. However, until the late 80 s they accounted for only about $5 \%$ of international road transport (Whitelegg, 1988; Bernadet, 1997 and Degli Abbati, 1987). The first two tables in Appendix B show how the number of community quota authorizations changed between 1969 and 1992. By 1993, the for-hire segment was deregulated in that limitations on the number of these permits were lifted. Own-account

\footnotetext{
${ }^{7}$ Usually bilateral agreements included the authorization to transit through a third country. Sometimes however third countries did not recognize transit authorizations in which case a specific permission to transit had to be obtained from such third countries or separate bilateral agreements could be established with the third country.

${ }^{8}$ Specifically, there were two types of authorization: authorization by trip and authorization by time. The trip authorizations allowed a predetermined number of trips to be completed in a specified time-period. The time authorizations were valid for a year and covered an indeterminate amount of trips within that time. Typically such agreements were negotiated by the countries' governments every year. Each government then distributed these authorizations among its carriers however it saw fit.

${ }^{9}$ See Council Decision 80/48/EEC of 20 December 1979 on the adjustment of capacity of carriage of goods by road for hire between member states (OJ L 18 24/1/1980).

${ }^{10}$ Council Regulation N. 1018/68 published in the OJ L 175 of 23/7/1968. The initial quota was for a total of 1200 authorizations and covered only for-hire carriers. For extensions of this regulation, see degli Abbati (1987) pp 105106.
} 
transport within the EU, in contrast, was declared free of quota or authorization requirements in $1980 .^{11}$

\section{Under European Conference of Ministers of Transport (ECMT) quota arrangements.}

These quotas are similar to Community quotas but apply to most ECMT countries. ${ }^{12}$ These permits are available only for the for-hire transport sector, and are quite limited in number. In 1994 the total number of such authorizations was 4100, less than the amount that was available in 1973 to the (then) nine member of the EU. They are currently - and were throughout the period of this study - mostly used for transit from European Community countries to non-EU countries rather than within the EU.

4. For types of transport exempt from quotas. This was the case in particular for goods that traveled in part by rail, for some exempt commodities ${ }^{13}$ and for transport with Switzerland, Andorra, Monaco and Lichtenstein, countries that are part of the ECMT, but not the EU, and that completely liberalized access of freight carriers to their territory prior to the start of our data period. This also applied to all trucks with a payload weight smaller than or equal to 3.5 tons. Moreover all for-hire transport within $25 \mathrm{~km}$ on either

\footnotetext{
${ }^{11}$ Council Directive 80/49/EEC published in OJ L 18 24/1/1980, amended by Council Regulation 881/92 published in the OJ L 095 of 09/04/1992. However the definition of own-account transport is somewhat restrictive in that it allows own-account transport only for vehicles driven by employees of the transporting firm. This does not allow own-account firms to rent trucks and drivers, for example, or to make use of a temporary driver. See Appendix A. ${ }^{12}$ The ECMT is an inter-governmental organization established in 1953, that constitutes a forum for the Ministers of Transport of various European countries, not limited to EU members. Until the end of the 1980s it included EU members, EFTA members (Switzerland, Finland, Norway, Sweden and Austria) plus Yugoslavia and Turkey. Eastern and Central European countries joined after the end of the communist block and currently the ECMT has 43 members including the 15 members of the EU. These multilateral authorizations are valid in all the member countries of the ECMT and include transit permits. They are yearly authorizations, but each country can decide to divide an authorization in 12 monthly authorizations. Since these authorizations are only available for the for-hire segment, outside of the EU own-account transport still can only be performed under bilateral agreements.

${ }^{13}$ Exempt commodities are (from Council Regulation n 881/92, published in the OJ L 095 of 09/04/92):

- Carriage of mail as a public service

- Carriage of vehicles which have suffered damage or breakdown

- Carriage of goods in motor vehicles the permissible laden weight of which, including that of trailers, does not exceed six tons or the permissible payload of which, including that of trailers, does not exceed 3.5 tons.

- Carriage of goods by own account

- Carriage of medicinal products, appliances, equipment and other articles required for medical care in emergency relief, in particular for national disasters
} 
side of a border as the crow flies has been exempt from any authorization or quota requirement. ${ }^{14}$

In addition to these quotas or 'entry' regulations, carriers involved in international road transport also faced pricing restrictions. Bilateral agreements between member states typically specified price-brackets (that is a minimum and a maximum price) at which transactions could occur. These price brackets officially became 'suggested' prices in 1984, but member states could choose to maintain compulsory rates. ${ }^{15}$ In January 1990, prices were allowed to be set through market negotiation between the shipper and the carrier. However, even when these price brackets were officially binding, they never appear to have been enforced (Bayliss and Coleman, 1994 and Degli Abbati, 1987 p. 98). For that reason, our analyses below focus on the relaxation of quotas or entry requirements rather than changes in price regulation.

Carriers involved in international road transport between EU members faced a number of other regulatory constraints that were relaxed during the 1980s and 1990s. First, there were lengthy controls at borders up until 1990 when these were eliminated. Second, carriers faced very strict restrictions on cross-trade transport and a complete prohibition on cabotage. Crosstrade transport is defined as international road transport performed by a motor vehicle registered in a third country. Such transport was only authorized under Community quotas. As the availability of such quotas increased, the restrictions on cross-trade transport became less stringent. Cabotage, on the other hand, is defined as transport within a member state that is performed by a carrier registered in a different country. The prohibition against cabotage was lifted gradually, as discussed below.

\footnotetext{
${ }^{14}$ See First council directive of 23 July 1962 on the establishment of certain common rules for international transport published in the OJ 70,6/8/1962 and all successive amendments.

${ }^{15}$ Council Regulation N. 3568/83 published in the OJ L 359, 22/12/1983.
} 
This set of rules concerning who could carry what where existed despite the fact that discrimination based on the nationality of the carrier was supposed to be illegal among EU member countries. Indeed, the 1957 Treaty of Rome that established the European Economic Community stated that a common transport policy had to be achieved by December 1969. This was still not the case in the early 80s, so in 1985 the Court of Justice ruled that member states had to enact legislation in order to achieve a free international market for road freight transport. Following this ruling a progressive liberalization started taking place. In 1987, the number of community permits was greatly increased: specifically, the number of Community authorizations increased by $40 \%$ each year between 1987 and $1992 .{ }^{16}$ All limitations on the number of permits were eliminated in 1993 with the introduction of Community licenses, which are 5-year renewable licenses allowing a carrier to transport anywhere within the EU. The increase in Community authorizations for international road transport and the creation of Community licenses also implicitly relaxed and then lifted all regulations regarding cross-trade transport.

Later in 1990, as noted above, controls at borders within the European Union were eliminated, cutting down times for international road transport. ${ }^{17}$ Also, in July 1990, a limited number of permits to perform cabotage operations were introduced which were restricted to forhire carriers only. Specifically, between July 1990 and July 1991 the EU created 15,000 authorizations (equivalent to 2,500 yearly permits). ${ }^{18}$ This number was increased by $10 \%$ in 1991-1992 and another 10\% in 1992-1993. The final solution to the cabotage issue was adopted with EU regulation 3118/93 which stated that starting on January 1, 1994 the number of cabotage

\footnotetext{
${ }^{16} 50 \%$ of the additional permits each year were allocated 'linearly', that is in proportion to the total number of permits that a country detained the previous year, and the remaining $50 \%$ were allocated based on the effective utilization rates of permits in each country (Bernadet, 1997). See Appendix B for details.

${ }^{17}$ Arguably this could have pushed towards greater intra-European trade as firms restructured and centralized their production activities. We discuss this further below.

${ }^{18}$ EU regulation 4059/89 authorized cabotage for the for-hire transport sector starting in July 1990. Cabotage authorizations could only be assigned to motor carriers that had a community authorization for international transport. It was valid for two months (but could be divided into two authorizations of one month each). It could be used by any vehicle owned by the transport company.
} 
authorizations were to be increased systematically until July 1, 1998 when the need for cabotage authorizations would be eliminated. ${ }^{19}$ Note that in 1994, EU regulation 792/94 also authorized own-account carriers to perform cabotage operations. Prior to that date, own-account continued to face a complete prohibition on cabotage. This was the only area where own-account faced more stringent rules than did the for-hire segment.

During this same time period, there were few changes in the regulation of other modes of international transport in the EU. Rail freight transport remained fairly heavily regulated throughout the period of this study though legislation enacted in the 1990s set the ground rules for a slow liberalization to occur in the rail freight industry starting in March 2003. Seaports were neglected by EU policy during the 1970s and 1980s. In the early 1990s investments in ports increased significantly. Also, the amount of freight transported through inland waterways did not substantially change during the 80 s and 90 s although the adoption of containerization allowed this mode of transport to become much more efficient and to considerably reduce the number of vessels used.

\section{Conceptual framework and hypotheses}

\subsection{Liberalization and the Amount of International Road Transport}

Prior to liberalization the regulatory regime imposed high costs on the transport of goods across borders by road, both because of the need to secure permits and because of timeconsuming border controls. This likely led carriers to make detours, add inefficient hauls, perhaps refuse certain hauls (for example hauls that did not originate or end in the country where the carrier was registered), and so on. In fact, largely due to the various constraints imposed by

\footnotetext{
${ }^{19}$ In order to take into account the fact that new members had entered the EU, EU regulation 792/94 further increased cabotage authorizations by $54 \%$ for 1995 and another 30\% per year until July 1, 1998 when the need for cabotage authorizations was eliminated. For the exact number of authorizations over time, see appendix B.
} 
the regulatory regime, about $40 \%$ of the trucks crossing borders were traveling empty in the EU during the late 1980 s. $^{20}$

To the extent that liberalization, be it the growth in the number of authorizations or the liberalization of cabotage and cross-trade transport, has allowed carriers to combine loads more efficiently, or to use more direct or otherwise better routing, it should reduce the cost of international road transport relative to local road trucking and to other modes of freight transportation. Assuming that these reduced costs are passed on to consumers in the form of lower prices, deregulation will lead to significant growth in international road transport due to its lower relative price. $^{21}$

\subsection{Liberalization and the Use of For-Hire versus Own-Account Carriage}

The choice between for-hire and own-account haulage for a shipper involves a number of trade-offs. Shippers whose loads need to be highly coordinated with production needs or whose customer service requirements are high may tend to use own account haulage (Hubbard, 2001, Baker and Hubbard, 2003, Nickerson and Silverman, 2003). For-hire carriage, however, will typically be more cost efficient. Specifically, for-hire carriers are better able to maintain high loading factors for their trucks and reduce the trucks' idle time (thereby reducing their unit cost) for a number of reasons. First, for-hire firms tend to be less sensitive to demand volatility because they serve the transportation needs of a portfolio of firms. Second, in the period under study in Europe, private carriers were not allowed to take on third-party freight. Finally, even

\footnotetext{
${ }^{20}$ This is a very large amount compared to the US. Moore (1991) reports that prior to deregulation $28 \%$ of own account carriers in the US had empty backhauls. The amount of empty backhauls for for-hire carriers is typically lower because they are better able to secure backhauls.

${ }^{21}$ Lower transportation costs also might increase the incentives of companies to source or sell more internationally, thereby increasing the amount of international trade. We do not believe this potential endogeneity problem should affect how we interpret our results for two main reasons. First, the impact of lower international transport costs on the amount of international trade is likely to be negligible compared to the overall effect of EU enlargement and of the push towards a single European market. Second, in our empirical analyses, we examine the effects of deregulation after controlling for changes in international trade. If lower international road freight transport costs spurred increases in international trade, our results will be biased against our finding a direct deregulation effect.
} 
when private carriers can take on third-party freight, for-hire firms are better able to identify and coordinate complementary demands. In order to find hauls and backhauls a carrier has to build expertise in the market and a web of potential shippers (see e.g. Baker and Hubbard, 2003). A firm whose primary activities lies outside of trucking is less likely to be successful at regularly identifying and pricing good matches for its hauls. Private carriers will therefore end up typically with a higher percentage of empty backhauls.

While the decision to outsource transportation needs depends on a number of factors, liberalization has only affected specific aspects of this equation. Prior to the period of our study, in the 1960s and 1970s, both own-account and for-hire carriers were subject to the same permit requirements. In the early 1980s, however, a Council directive exempted own-account transport from any quota or authorization requirement. Consequently, the increased availability of community licenses that occurred through liberalization in the 1980s had an impact only on the for-hire segment, reducing its cost relative to the already liberalized private haulage. These lower costs, assuming they were passed on to consumers of road transport in the form of lower prices, should make the 'buy' option relatively more attractive to shippers. We therefore expect licensing deregulation, which occurred throughout the 1980s and early 1990s, to increase the proportion of international road transport performed by for-hire carriers.

Another aspect of deregulation that may affect the relative reliance on for-hire and private haulage relates to cabotage. Changes in regulation for cabotage were implemented initially for for-hire haulage only, and then for own-account haulage. If such regulations were constraining, and the amount of deregulation economically significant, one would expect the deregulation to have a positive effect on the proportion of for-hire during the period of preferential treatment (1991-1994). 


\subsection{The Effect of Liberalization on Member State Transport Intensity}

National governments in Europe are often concerned that changes in regulation will go to the advantage of other countries. In the case of international road freight transport deregulation, there were two major concerns. First of all, large countries that had been strictly regulated, such as France and Germany, were afraid that deregulation would favor carriers of countries that were more open, such as the Netherlands and Belgium. Second, they were concerned that large amounts of international trucking would be captured by carriers of countries with low labor costs, such as Portugal and Spain. ${ }^{22}$

Prior to liberalization the distribution of international road transport activities across member countries was determined predominantly by each country's set of bilateral agreements. This gave an advantage to transporters registered in countries with more extensive sets of agreements. ${ }^{23}$ They could provide a larger amount of international transport services relative to trucking companies in countries with fewer agreements.

As deregulation progressed, two opposing forces affected the distribution of road transport activities across countries. On the one hand, carriers from countries that were operating under a more liberalized regime - i.e. with more bilateral agreements - prior to liberalization may have been more efficient and therefore in better position to take advantage of the deregulated environment. On the other hand, deregulation reduced the importance of a transporter's country of origin in securing freight, allowing carriers of countries with originally fewer agreements to take advantage of the deregulated environment. Depending on which of these effects dominated, deregulation may have led to an increase or decrease in the transport intensity of those countries that were responsible for a disproportionately high share of international road transport within

\footnotetext{
${ }^{22}$ Such fears are not limited to the EU: e.g., see ECMT (2002).

${ }^{23}$ Of course, it is also true that countries with more or larger registered road transporters potentially had greater incentives to negotiate more agreements. Thus the advantage of country of origin could be self-sustaining.
} 
the EU prior to deregulation. We explore this question and the effect of labor cost differentials empirically below.

\section{The Data}

We obtained the road transport data mostly from Eurostat, the European statistical institute. The information on t-kms transported is a harmonized collection of observations from each EU country each year, spanning the 1982-2002 period. ${ }^{24}$ Typically the information is for trucks with a payload weight of more than 3.5 tons. ${ }^{25}$ We complemented and corrected the data using the ECMT database. ${ }^{26}$ The data include information on the amount of international haulage performed by carriers of the reporting countries (in thousand million t-kms). ${ }^{27}$ Neither $\mathrm{t}$ kms transported under the cabotage regime (available after 1991) or cross-trade transport are included in these figures, and we do not analyze the amount of such transport either, as the data on these were not collected reliably prior to $1999 .^{28}$ Finally, the data distinguish t-kms transported by for-hire and by own-account operators.

The data include information for all countries that are members of the EU during the 1982 to 2002 period. In 1982 there were ten member countries; that number had grown to 15 by 1995. ${ }^{29}$ Since an important part of the deregulation process ended in 1993, the empirical analyses below focus on the 12 countries that joined the EU prior to 1990, namely Belgium, Denmark, Germany, Greece, France, Ireland, Italy, Luxembourg, the Netherlands, Portugal,

\footnotetext{
${ }^{24}$ Prior to 1999 the data were based in part on customs data. In 1999, data collection at borders was dismantled, so the data since then have been collected through surveys.

${ }^{25}$ Exact information on the parameters used by each country is not available.

${ }^{26}$ Specifically, when data appeared extremely different in adjacent years, I compared with the ECMT data and used the latter if they seemed more plausible.

${ }^{27}$ The data on inbound (from a foreign country to the declaring country) and outbound (from the declaring country to a foreign country) carriage were added together to obtain total t-kms per country

${ }^{28}$ We have verified, however, that our results are the same if we use the total amount of $\mathrm{t}$-kms transported, including cabotage and cross-trade transport, as our dependent variable. For more on the data problems with these, see the methodological notes in EU (2004).

${ }^{29}$ See appendix $\mathrm{C}$ for a short history of the enlargement of the EU.
} 
Spain and the UK. In what follows, however, Belgium and Luxembourg are considered a single jurisdiction: the Belgium-Luxembourg Economic Union.

To control for the increased trade among EU members, we obtained data on international trade flows from the IMF Direction of Trade database. For each country we measure total EU trade, namely trade (imports plus exports) with countries that are part of the EU at any given time. This variable captures the increased trade due to German reunification as well as enlargement in addition to increased trade among those countries that are already members of the EU. Because the transport data are measured in real terms $(\mathrm{t}-\mathrm{kms})$, we converted the trade data to 1990 US dollars. ${ }^{30}$ Finally, we control for the price of inputs in some of our analyses. We use the price of diesel fuel including all taxes and expressed in real - as opposed to nominal - ECUs (European Currency Units) for that purpose. ${ }^{31}$

For most of the nine countries ${ }^{32}$ that were part of the EU prior to 1982 , there are 21 observations available. ${ }^{33}$ Spain and Portugal joined the EU in 1986, so there are 17 observations for these. The price of diesel (by country) is available starting in 1985, so the time series is a bit shorter (18 observations per country).

As for the measurement of deregulation, we show in Appendix B the number of EU permits for road transport assigned to carriers, by carriers' country of origin, and the number of cabotage permits as well, during the period of analysis. Since there are no EU permits issued after 1993, when entry into international road transport was fully deregulated, we cannot tell how many authorizations full deregulation corresponds to. As a result, any measure of deregulation

\footnotetext{
${ }^{30}$ They are in current US dollars in the source. We first converted them to national currency, then deflated the figures for each country with the appropriate price deflator, and finally reconverted them to US dollars using the exchange rate for 1990 .

31 The fuel price data was originally in nominal terms, and by semester. We use the average of the semester data each year as our annual measure, and deflate these using a CPI deflator.

${ }^{32}$ For simplicity, we refer to countries in what follows even though one of the jurisdictions is actually an economic union of two countries: Belgium and Luxembourg.

${ }^{33}$ Some of the yearly data are missing for some countries: Greece, Ireland and Italy have respectively 4, 5, and 8 missing observations.
} 
will be somewhat arbitrary. For this reason, in much of what follows, we use a simple step function, setting the authorization deregulation variable equal to 0 for all years prior to 1985 (complete regulation), to 0.5 between 1985 and 1993 (partial deregulation), and 1 after 1993 (complete deregulation). Similarly, we define a cabotage deregulation variable equal to 0 prior to 1990 (when none was allowed), 0.5 between 1990 and 1998 (limited availability of authorizations) and 1 starting in 1998 (when it was completely liberalized). One way to think about these measures is that they capture the level of information available or relevant to market participants. Specifically, individuals and firms may be able to tell when the market is fully regulated, partially deregulated, and fully deregulated, but may not know or associate the exact number of EU permits in their countries with an exact "degree" of deregulation at any given time. Note that these variables also implicitly assume that the degree of deregulation is the same across countries at any given point in time. While this is not strictly correct (see below), differences in rates of deregulation were minimal. This, in turn, limits the empirical strategies open to us. $^{34}$

To see the results we might obtain with a more "precise" measure, however, we also used a deregulation variable that we set equal to zero prior to deregulation and 100 from 1993 (or 1998 for cabotage) onward. Between those two periods, we calculate the extent of deregulation using the number of authorizations allocated to each country each year in proportion to what we expect total deregulation to require. We assume specifically that the market is $90 \%$ deregulated by the last year of partial deregulation (1992 for international authorizations and 1997 for cabotage). This assumption seems reasonable given the observed growth in international transport after full deregulation. This assumption then allows us to calculate the required number of authorizations that would correspond to full deregulation at the time it was implemented as

\footnotetext{
${ }^{34}$ In particular, we cannot rely on a difference-in-difference estimation strategy. Instead, we try to provide more descriptive evidence to strengthen our arguments, along with a number of robustness tests.
} 
$\mathrm{N}_{\mathrm{c}}{ }^{*}=(100 / 90) \mathrm{N}_{\mathrm{c}}$, where $\mathrm{N}_{\mathrm{c}}$ stands for the number of authorizations available for that country the last year of partial deregulation. The degree of deregulation in year $t$ for country $\mathrm{c}$ is then calculated as $\left(\mathrm{x}_{\mathrm{ct}} / \mathrm{N}_{\mathrm{c}}{ }^{*}\right) 100$, where $\mathrm{x}_{\mathrm{ct}}$ is the number of licenses available to country $\mathrm{c}$ in year $\mathrm{t}$. This variable allows us not only to capture the extent of deregulation overall on a more continuous basis, but it also captures the fact that the level of deregulation was not exactly the same across countries at any given time.

Border deregulation is measured as a single dummy variable set equal to zero prior to 1990 and one thereafter. We report summary statistics for all these variables in Table 1.

Table 1. Summary statistics (country-level data, years 1982-2002)

\begin{tabular}{|l|c|r|r|r|r|}
\hline Variable & \multicolumn{1}{c|}{ Obs } & \multicolumn{1}{c|}{ Mean } & \multicolumn{1}{c|}{ Std. Dev. } & \multicolumn{1}{c|}{ Min } & \multicolumn{1}{c|}{ Max } \\
\hline $\begin{array}{l}\text { Road total } \\
\text { ton-kms (millions) }\end{array}$ & 206 & $16,280.58$ & $12,035.04$ & 409 & 51,160 \\
\hline $\begin{array}{l}\text { Ton-kms road x 100 } \\
\text { /ton-kms all modes }\end{array}$ & 153 & 72.51 & 22.15 & 28.94 & 100 \\
\hline $\begin{array}{l}\text { International ton-kms x 100 } \\
\text { /nat.+ internat. ton-kms) }\end{array}$ & 203 & 27.43 & 17.56 & 3.37 & 60.73 \\
\hline Percent for-hire & 206 & 92.82 & 6.87 & 66.31 & 100 \\
\hline \hline $\begin{array}{l}\text { All modes total ton-kms } \\
\text { (millions) }\end{array}$ & 153 & $30,397.48$ & $25,479.29$ & 660 & 104,694 \\
\hline National ton-kms (millions)** & 205 & $64,921.27$ & $62,605.49$ & 3,726 & 230,016 \\
\hline \hline Trade (billion US \$) & 223 & 165.81 & 130.1 & 10.52 & 571.76 \\
\hline Diesel price & 196 & 525.77 & 131.34 & 212.93 & 959.99 \\
\hline
\end{tabular}

Notes: Ton-kms in the table always refer to international ton-kms, unless explicitly noted.

*: Includes international transport by road, rail and inland waterways. Note that Denmark is missing 9 observations, Spain, 5, France, 6, Greece, 4, Ireland, all, Italy, 11, Portugal, 2, and the UK, 12.

**: Missing observations for national road transport: Italy, 7 observations, Portugal and Spain, one observation each, Greece, 4, and Ireland, 5 observations.

\section{Specification and results}

\subsection{Effects of deregulation on quantity of international road transport}

Figure 1 shows how total international road transport changed between 1982 and 2002 for the six countries for which we have full time series data, namely BLEU (BelgiumLuxembourg Economic Union), Denmark, Germany, France, the Netherlands, and the United 
Kingdom. These six countries were members of the EU throughout the data period, and are also the ones with the most reliable data collection systems. These six countries accounted for about $95 \%$ of total international t-kms in the early 1980s. This proportion decreased somewhat over time as more countries joined the EU. It stood at about $75 \%$ of total international road t-kms in the late 1990s.

Figure 1 shows that the growth in international road transport has been strong throughout the liberalization period, for both small and large countries. Interestingly, the growth in other modes of transport was much more modest during the same period, despite being influenced by the same expansion in trade (see EU 1999 and 2000). This implies an increased reliance on international trucking in the EU relative to the other modes of transportation. We explore whether and how the different types of deregulation may have contributed to this by estimating the following regression equation:

$$
\begin{aligned}
& T_{c t}=\alpha_{c}+\beta \text { authorization }_{c t}+\gamma \text { cabotage }_{c t}+\zeta \text { borderdere }_{t}+\mu \text { trade }_{c t}+ \\
& +v \text { dieselprice } \\
& c t
\end{aligned}
$$

where the dependent variable is international transport by road performed by carriers of country c in year t. Assuming that all three forms of regulation were binding, we expect all three deregulation variables, borderdereg, authorizations, and cabotage, to have positive effects on international road transport. As for our control variables, we expect each country's level of international trade with other EU members to be positively associated with international road transport. $^{35}$ The average yearly price of diesel (by country), on the other hand, increases operating costs in road transport. If this effect is high for road transport relative to other modes, then increased fuel prices should reduce the amount of international road transport.

\footnotetext{
${ }^{35}$ Of course less expensive road transport, due to deregulation, may also lead to increased trade. By controlling for trade, however, we can assess if deregulation has had a direct effect on road transport net of this effect on trade.
} 
Table 2 shows the results from estimating equation (1) with country fixed effects, i.e. assuming that $\varepsilon_{\mathrm{ct}}=\mathrm{e}_{\mathrm{c}}+\mu_{\mathrm{ct}}$, as we need to control for the time-invariant, unobserved characteristics of each country. ${ }^{36}$ The first two columns show results obtained with all available data for the 11 countries that joined the EU prior to 1995. In the first of these results are obtained using our more continuous "proportion" deregulation variables, whereas the second column shows results from our step variable measures of deregulation. The next two columns show results obtained for the sub-sample of six countries for which we have complete time-series data, using the same two ways to measure deregulation.

Table 2. Country-level. Dependent variable: total ton-kilometers

\begin{tabular}{|c|c|c|c|c|}
\hline & \multicolumn{2}{|c|}{11 Countries* } & \multicolumn{2}{|c|}{6 Countries } \\
\hline & $\begin{array}{l}\text { "Proportion" } \\
\text { Deregulation }\end{array}$ & Step Variables & $\begin{array}{l}\text { "Proportion" } \\
\text { Deregulation }\end{array}$ & Step Variables \\
\hline Authorization deregulation & $\begin{array}{l}4,128.73+ \\
(2,443.04)\end{array}$ & $\begin{array}{l}4,103.30^{*} \\
(1,694.50)\end{array}$ & $\begin{array}{l}8,635.88^{* *} \\
(2,546.14)\end{array}$ & $\begin{array}{l}6,666.12^{* *} \\
(1,646.90)\end{array}$ \\
\hline Cabotage deregulation & $\begin{array}{l}2,679.08+ \\
(1,572.92)\end{array}$ & $\begin{array}{c}2,071.36 \\
(1,591.21)\end{array}$ & $\begin{array}{c}926.87 \\
(1,808.10)\end{array}$ & $\begin{array}{c}-266.76 \\
(1,775.71)\end{array}$ \\
\hline $\begin{array}{l}\text { Border deregulation } \\
\text { (1990 dummy) }\end{array}$ & $\begin{array}{c}46.22 \\
(1,563.00)\end{array}$ & $\begin{array}{c}1,437.94 \\
(1,043.32)\end{array}$ & $\begin{array}{c}-339.25 \\
(1,621.88)\end{array}$ & $\begin{array}{c}3,352.67 * * \\
(1,072.85)\end{array}$ \\
\hline Diesel price & $\begin{array}{l}-0.86 \\
(3.60)\end{array}$ & $\begin{array}{l}-0.18 \\
(3.67)\end{array}$ & $\begin{array}{l}-5.89 \\
(4.38)\end{array}$ & $\begin{array}{l}-2.69 \\
(4.35)\end{array}$ \\
\hline Trade & $\begin{array}{c}49.63 * * \\
(8.27)\end{array}$ & $\begin{array}{c}51.71 * * \\
(7.79)\end{array}$ & $\begin{array}{c}38.84 * * \\
(7.27)\end{array}$ & $\begin{array}{c}40.86^{* *} \\
(6.81)\end{array}$ \\
\hline Country Fixed Effects & Yes** & Yes** & Yes** & Yes** \\
\hline Constant & $\begin{array}{l}4,749.08^{*} \\
(2,343.45) \\
\end{array}$ & $\begin{array}{r}3,117.81 \\
(2,423.59) \\
\end{array}$ & $\begin{array}{l}9,252.32 * * \\
(3,002.44) \\
\end{array}$ & $\begin{array}{l}6,054.12^{*} \\
(2,872.16) \\
\end{array}$ \\
\hline Observations $* *$ & 182 & 182 & 108 & 108 \\
\hline R-squared & 0.61 & 0.61 & 0.76 & 0.76 \\
\hline
\end{tabular}

Standard errors in parentheses; + significant at $10 \% ; *$ significant at $5 \% ; * *$ significant at $1 \%$

*: The 11 country regressions include Greece, although total t-kms for Greece is set equal to for-hire t-kms because Greece never reports own-account information

**: Since diesel price is only available after 1985, the sample size is reduced by 24 for the 11 -country set and by 18 fewer for the 6-country regressions.

Though magnitudes and significance levels differ, the results are quite consistent overall.

Most importantly, we find that the liberalization of the authorization system has had the expected

\footnotetext{
${ }^{36}$ As the deregulation variables do not vary significantly (or at all in the case of step variables) by country, there is no real "between" estimator for our coefficients of interest, and thus no basis for a "random" effects estimator that would be different from the fixed-effects estimator.
} 
positive effect on the total amount of t-kms, and this even after we control for increased trade by country within the EU. The effect of the liberalization of licenses is quite large, at more than 4000 (6000) million ton-kms, on average, when we go from 0 to $100 \%$ deregulation for the 11 (6) countries in our sample. Note that, from table 1, the mean for total international t-kms transported by road is 16,281 million. The effect of the cabotage variable is generally positive, but statistically significant only for the 11-country set when the deregulation variable is measured on a proportional basis. The lack of significant effect is not so surprising considering that the amount of cabotage remained quite low even when permits became available (Allen, 2000 and Commission of the European Communities, 2000). Border deregulation also has the expected positive effect on the amount of international road transport, but this effect is not robust across our specifications. ${ }^{37}$ The price of diesel has the expected negative effect on the total amount of international road transport, though this effect is not measured with enough precision to be statistically different from zero.

Table 3 shows results obtained when we control for increased trade in alternative ways. Specifically, we now define the dependent variable as either the percent of international road trato the sum of national and international road freight transport (columns 1 through 4), or the percent of road t-kms to total t-kms transported by road, rail and inland waterways (columns 5 and 6). Because we have limited data on transport via other modes, we present results for our larger unbalanced sample only for the latter. Also, since we do not expect that diesel prices would affect national and international road transport differently, we eliminate this variable from the first four regressions, allowing us to increase our sample sizes somewhat.

\footnotetext{
${ }^{37}$ The results suggest that this may be due to a spurious interaction between our deregulation variables. For example, if we exclude the cabotage deregulation variable from our regressions in Tables 2 and 3 , the explanatory power of the regressions is unaffected and the coefficients of the other two deregulation variables become more positive. Hence, overall, the results imply a positive effect of deregulation in all our regressions - we simply cannot disentangle the effects of the various types of deregulation as clearly as one would like.
} 
Results in columns 1 through 4 imply that the international road transport sector has grown relative to national road transport as international-specific changes in regulation have been implemented. Specifically, though the effects of our deregulation variables are not all individually significant, taken together our evidence suggests that the proportion of international to total national and international transport has grown by about 5 to 6 percentage points - per the sum of the coefficients for the deregulation variables - as the different types of deregulation were implemented in our larger set of countries. If we focus on the 6 countries with more complete data, we find much stronger effects and our regressors explain much more of the variation in the dependent variable, confirming that the 11 country data is quite noisy. Note that during this period of time, many individual countries were also deregulating their domestic road freight sectors. This, however, happened at different times and in different ways in the various jurisdictions. Our finding that international road freight transport has grown relative to national road freight transport during this period suggests that factors influencing the amount of international transport went beyond those that influenced national road transport - which include trade and GDP growth. Our interpretation is that, as it was subject to especially heavy regulation, international road transport was disproportionately affected by its own, EU-level, deregulation. Note that the coefficient on trade is negative in these regressions. Though not always statistically different from zero, this negative coefficient suggests that national road transport has grown more rapidly than international road transport has as a result of increased trade.

There is limited information on the amount of international freight transported by modes other than road. Ireland, for example, lacks the information completely. Consequently, analyses shown in columns 5 and 6 , where the dependent variable is the ratio of international road freight transport to total international freight across all modes, is carried out on ten rather than eleven countries. We include the price of diesel among the regressors in these analyses because road 
freight transport potentially consumes more fuel per ton-km than rail or inland waterways. However, we find that the price of diesel really has no effect on the share of international road freight transport versus other modes. Trade, on the other hand, has a positive and statistically significant effect on this share, suggesting that road transport has been chosen for an increasing portion of the total international transport resulting from the process of growth and integration of the EU. Simplifying border crossing also seems to have increased the share of total international transport that is accounted for by road transport. Most importantly, the deregulation of authorizations has had a positive and statistically significant effect on the extent to which shippers rely on international road transport relative to other modes: the percent of international road transport, relative to all modes, increases by 3.6 or 5.6 percentage points, depending on which deregulation measure we use, when the deregulation of licenses goes from 0 to $1 .^{38}$

Table 3. Country level: Alternative dependent variables.

\begin{tabular}{|c|c|c|c|c|c|c|}
\hline & \multicolumn{4}{|c|}{$\begin{array}{l}100 * \text { Total International Road / } \\
\text { Total National + Int'l Road }\end{array}$} & \multirow{2}{*}{\multicolumn{2}{|c|}{$\begin{array}{c}100 * \text { Total Road/ } \\
\text { Total All Modes } \\
10 \text { Countries* } \\
\end{array}$}} \\
\hline & \multicolumn{2}{|c|}{11 Countries* } & \multicolumn{2}{|c|}{6 Countries } & & \\
\hline & $\begin{array}{l}\text { "Proportion" } \\
\text { Deregulation }\end{array}$ & $\begin{array}{c}\text { Step } \\
\text { Variables } \\
\end{array}$ & $\begin{array}{l}\text { "Proportion" } \\
\text { Deregulation }\end{array}$ & $\begin{array}{c}\text { Step } \\
\text { Variables } \\
\end{array}$ & $\begin{array}{l}\text { "Proportion" } \\
\text { Deregulation }\end{array}$ & $\begin{array}{c}\text { Step } \\
\text { Variables } \\
\end{array}$ \\
\hline $\begin{array}{l}\text { Authorization } \\
\text { deregulation }\end{array}$ & $\begin{array}{l}2.16 \\
(2.65)\end{array}$ & $\begin{array}{c}2.22 \\
(1.57)\end{array}$ & $\begin{array}{l}6.56^{*} \\
(2.68)\end{array}$ & $\begin{array}{l}5.73 * * \\
(1.45)\end{array}$ & $\begin{array}{l}5.64 * \\
(2.34)\end{array}$ & $\begin{array}{l}3.59 * \\
(1.65)\end{array}$ \\
\hline $\begin{array}{l}\text { Cabotage } \\
\text { deregulation }\end{array}$ & $\begin{array}{l}2.84+ \\
(1.71)\end{array}$ & $\begin{array}{l}2.96+ \\
(1.70)\end{array}$ & $\begin{array}{c}0.86 \\
(1.75)\end{array}$ & $\begin{array}{c}0.85 \\
(1.67)\end{array}$ & $\begin{array}{l}-1.52 \\
(1.77)\end{array}$ & $\begin{array}{c}0.40 \\
(1.72)\end{array}$ \\
\hline $\begin{array}{l}\text { Border } \\
\text { deregulation } \\
\text { (1990 dummy) }\end{array}$ & $\begin{array}{c}1.46 \\
(1.80)\end{array}$ & $\begin{array}{l}1.65 \\
(1.19)\end{array}$ & $\begin{array}{c}0.95 \\
(1.84)\end{array}$ & $\begin{array}{l}2.63 * \\
(1.16)\end{array}$ & $\begin{array}{c}0.29 \\
(1.45)\end{array}$ & $\begin{array}{l}2.15^{*} \\
(1.00)\end{array}$ \\
\hline Diesel Price & & & & & $\begin{array}{c}0 \\
(0.004)\end{array}$ & $\begin{array}{c}0 \\
(0.004)\end{array}$ \\
\hline Trade & $\begin{array}{l}-0.01 \\
(0.01)\end{array}$ & $\begin{array}{l}-0.01 \\
(0.01)\end{array}$ & $\begin{array}{c}-0.02 * * \\
(0.01)\end{array}$ & $\begin{array}{c}-0.02 * * \\
(0.01)\end{array}$ & $\begin{array}{c}0.03 * * \\
(0.01)\end{array}$ & $\begin{array}{c}0.03 * * \\
(0.01)\end{array}$ \\
\hline $\begin{array}{l}\text { Country Fixed } \\
\text { Effects }\end{array}$ & Yes** & Yes** & Yes** & Yes** & Yes** & Yes** \\
\hline Constant & $\begin{array}{c}26.06 * * \\
(1.32) \\
\end{array}$ & $\begin{array}{c}25.72 * * \\
(1.22)\end{array}$ & $\begin{array}{c}32.05 * * \\
(1.47)\end{array}$ & $\begin{array}{c}31.91 * * \\
(1.31)\end{array}$ & $\begin{array}{c}64.61 * * \\
(2.48)\end{array}$ & $\begin{array}{c}64.93 * * \\
(2.53) \\
\end{array}$ \\
\hline Observations & 203 & 203 & 126 & 126 & 135 & 135 \\
\hline
\end{tabular}




\begin{tabular}{lcccccc} 
R-squared & 0.19 & 0.19 & 0.39 & 0.43 & 0.43 & 0.43 \\
\hline Standard errors in parentheses; & + significant at $10 \% ; *$ significant at $5 \% ; *$ significant at $1 \%$
\end{tabular}

\subsection{Effects on percent of total transport operated by for-hire carriers}

Figure 2 displays the evolution of the for-hire share of total international freight trucking for the six European countries for which we have complete time series data between 1982 and 2002. It shows that the share of for-hire trucking has increased in all six countries during this period, and especially in the Belgium-Luxembourg union which started from the lowest share of for-hire transport. We explore whether deregulation contributed to this change by estimating the following:

$$
\% \text { forhire }_{c t}=\alpha_{c}+\beta \text { authorizations }_{c t}+\gamma \text { cabotagedummy }_{t}+\varepsilon_{c t}
$$

where \%forhire stands for the percent of total ton-kilometers transported by for-hire carriers in country c at time t. As before, the variable authorizations captures the deregulation of the system of licenses for international road transport. The variable cabotagedummy replaces our earlier cabotage deregulation variable because what matters in equation (2) is not the number of licenses for cabotage and how it has changed over time, but rather the fact that for-hire trucking received preferential treatment - albeit to a limited extent - with respect to cabotage between 1991 and 1994. Thus cabotagedummy is set equal to 1 for the period 1991 to 1994 and is 0 otherwise. As there are no reasons to expect international trade or the price of diesel to influence the decision to outsource trucking services, these control variables are excluded from the current analyses. ${ }^{39}$ The 'full sample' results are limited to 10 countries because Greece never reports the amount of international own account road freight transport performed.

\footnotetext{
${ }^{39}$ There have been several studies in recent years (notably Hubbard, 2000 and Baker and Hubbard, 2003) that analyze the effects of on-board-computers on the make or buy decision in the trucking industry in the US market. Representatives of the European trucking industry were unanimous in regarding this as a non-issue in Europe
} 
Results from estimating equation (2) with country-level fixed effects are shown in table 4. They imply that increasing the number of licenses has a positive and statistically significant effect on the share of total transport operated by for-hire firms. Specifically, on average, moving from complete regulation to complete deregulation increased the percentage of for-hire transport from almost 7 to 9 percentage points. Moreover, consistent with earlier results, which suggested that cabotage was never a major issue or opportunity, the preferential treatment of for-hire in the cabotage liberalization process seems to have had - if anything - a negative effect on shippers' decision to integrate vertically or subcontract their transportation needs. Most likely the negative effect is due to some other concurrent change in the market - for our purposes, however, it mostly implies a lack of advantage associated with the short preferential treatment of the for-hire segment for cabotage. ${ }^{40}$

Note that the results are robust to our different measures of deregulation and do not vary significantly between the full and balanced panel data.

Table 4. Dependent variable: \% for-hire

\begin{tabular}{|c|c|c|c|c|}
\hline & \multicolumn{2}{|c|}{10 Countries } & \multicolumn{2}{|c|}{6 Countries } \\
\hline & $\begin{array}{l}\text { "Proportion" } \\
\text { Deregulation } \\
\end{array}$ & $\begin{array}{c}\text { Step } \\
\text { Variables } \\
\end{array}$ & $\begin{array}{l}\text { "Proportion" } \\
\text { Deregulation }\end{array}$ & $\begin{array}{c}\text { Step } \\
\text { Variables } \\
\end{array}$ \\
\hline $\begin{array}{l}\text { Authorization } \\
\text { deregulation }\end{array}$ & $\begin{array}{c}6.68 * * \\
(0.68)\end{array}$ & $\begin{array}{l}7.29 * * \\
(0.72)\end{array}$ & $\begin{array}{l}9.17 * * \\
(0.78)\end{array}$ & $\begin{array}{l}9.01 * * \\
(0.86)\end{array}$ \\
\hline $\begin{array}{l}\text { Cabotage dummy } \\
(1991-1994)\end{array}$ & $\begin{array}{r}-1.83^{*} \\
(0.72)\end{array}$ & $\begin{array}{l}-0.21 \\
(0.70)\end{array}$ & $\begin{array}{l}-2.03^{*} \\
(0.91)\end{array}$ & $\begin{array}{c}0.11 \\
(0.94)\end{array}$ \\
\hline Constant & $\begin{array}{c}88.10 * * \\
(0.50)\end{array}$ & $\begin{array}{c}87.28 * * \\
(0.56)\end{array}$ & $\begin{array}{c}85.02 * * \\
(0.57)\end{array}$ & $\begin{array}{c}84.64 * * \\
(0.65)\end{array}$ \\
\hline Observations & 189 & 189 & 126 & 126 \\
\hline R-squared & 0.35 & 0.36 & 0.54 & 0.48 \\
\hline
\end{tabular}

because there is very limited adoption of computers that go beyond what is mandated everywhere by law (trip recorders). We therefore do not consider any measure of adoption of on-board-computers in our analysis.

${ }^{40}$ For example, the use of just-in-time production processes grew during the period of our sample. If this increased the coordination needs of shippers, it might be expected to increase their desire to vertically integrate their transportation functions. The fact that we find the opposite trend in our raw data suggests that the liberalization of international transport rules had an even larger effect. 


\subsection{Effects on member state transport intensity}

National governments in Europe are often concerned that changes to the status quo will go to the advantage of other countries. This prompted us to look at the effects of deregulation on the specialization of member states in international transport. Specifically, we are interested in the extent to which deregulation may have affected how much different member states may "disproportionately" participate in international transport. We do this by first generating the following measure of relative transport intensity for country c at time t:

$$
\text { intensity }_{c t}=\frac{\int_{c t} / \sum_{c} T_{c t}}{G D P_{c t} / \sum_{c} G D P_{c t}}
$$

where $T_{c t}$ represents the amount of international road transport in ton-kilometers of the carriers of country c in year t, and GDP is Gross Domestic Product. This measure captures the degree to which a particular country 'specializes' in international road transport, that is the extent to which its share of international road transport diverges from its share of European GDP. We are interested in determining if the countries that are initially more specialized in international road freight transport specialize even more in this activity after deregulation. Also we want to explore if carriers of low-wage countries such as Spain, Portugal and Italy ended up with a much larger share of total international transport after deregulation.

Figure 3 shows the share of total international road transport accounted for by each of the six countries for which we have full time series with respect to the total amount of international road freight transport for those countries. Figure 4, in turn, shows how the intensity variable defined above has changed over time for these same countries. Neither graph suggests a clear effect of deregulation on the tendency for different countries to specialize more in, or get a larger 
share of, international road transport in Europe. Neither those with larger shares nor smaller shares before deregulation seem to gain disproportionately from the change. Instead, we see individual countries such as Germany lose share, but then regain it later; and the UK gains share in the mid-80s, but then starts losing it later on. The variability of our intensity index is larger for some countries, but the three countries with ratios below one - which means the three countries that do less international road transport than their GDP might "warrant" - remain there the whole time, and the three countries with ratios above one - which are all small countries through which much traffic must go - remain there over the full period as well, albeit with a degree of fluctuation in "intensity." Regression results (not shown), where we allow deregulation to affect high and low intensity countries differently - simply confirm that among the six countries for which we have full time series, deregulation has had basically no effect on their "degree of specialization" in international road transport.

We also address the fear that carriers of low-wage countries would take advantage of the deregulated environment: figure 5 shows the share of total international road freight transport performed by carriers of low-wage countries, i.e. Italy, Portugal and Spain. Carriers of these countries do not appear to have increased their share of total international transport dramatically. In fact the largest increase is for carriers located in Spain, but only for the later years of the sample when the wage differential with other European countries was in fact decreasing.

To explore the concern about industry distribution in a different way, we show in Table 5 how the Hirschman-Herfindahl index (HHI) of concentration across countries has changed over time. Specifically, the HHI index for each year is calculated as $\sum_{c}\left(s_{c}\right)^{2}$ where $s_{c}$ represents the share of EU international road transport performed by carriers based in country c. We present 
this measure first for our larger set of 11 member countries, followed by the same measure restricted to the six countries for which we have complete time series data.

The data in this table confirms that for the EU as a whole, the concentration of the international road freight industry has been steadily falling over the time covered by our data. This, of course, is not surprising given EU enlargement (see Appendix C for a brief summary). When we concentrate on only those six countries for which we have full data, we find a decrease in concentration from the mid 1980s to the mid 1990s, after which concentration increases. This suggests that the carriers of smaller countries, which started off with low shares of international road transport, gained share during the deregulation period. But from the mid 1990s, when full deregulation had occurred, the larger countries bounced back. In the end, we conclude that the net effect of deregulation on the transport share and intensity of each country, and thus on the concentration of the economic activity across countries, has been negligible.

\begin{tabular}{|c|c|c|c|c|c|}
\hline Year & HHI(11) & HHI(6) & Year & HHI(11) & HHI(6) \\
\hline 1982 & 1929 & 2096 & 1993 & 1305 & 1921 \\
\hline 1983 & 1900 & 2085 & 1994 & 1307 & 1903 \\
\hline 1984 & 1930 & 2089 & 1995 & 1221 & 1901 \\
\hline 1985 & 1946 & 2096 & 1996 & 1225 & 1956 \\
\hline 1986 & 1624 & 2098 & 1997 & 1236 & 1950 \\
\hline 1987 & 1558 & 2042 & 1998 & 1393 & 1971 \\
\hline 1988 & 1596 & 2085 & 1999 & 1173 & 2014 \\
\hline 1989 & 1353 & 2058 & 2000 & 1147 & 1979 \\
\hline 1990 & 1354 & 2041 & 2001 & 1174 & 2042 \\
\hline 1991 & 1326 & 2003 & 2002 & 1189 & 2043 \\
\hline 1992 & 1336 & 2021 & & & \\
\hline
\end{tabular}

\section{Conclusions}


In this paper we have described how the international road freight transport sector was deregulated in the European Union throughout the 1980s and 1990s, and we analyzed the effect of the deregulation on the industry on the extent and organization of the industry.

Deregulation in Western Europe was gradual and took place through many channels, including the gradual dismantlement of the system of authorizations allocated for international road transport, the elimination of border controls, and the lifting of rules concerning cabotage (the right to pick up and deliver within a country other than the one in which the carrier is registered). Our results imply that these changes had a large positive effect on the total amount of international road transport in the EU, even after controlling for the continuing process of economic integration that was occurring there over the same period. We also find that deregulation led more firms to rely on for-hire trucking firms for their road transportation needs. Both of these results are consistent with the notion that deregulation allowed road freight transportation companies to become more efficient and that, as these firms passed the costs savings to customers, the extent to which shippers chose to rely on road freight transportation increased. Thus we find evidence that deregulation was efficiency enhancing in Europe as it was in the United States.

Finally, we examined how the deregulation of the international trucking sector changed the concentration of this activity across EU member countries. We found that the effect of deregulation on this aspect of the industry was negligible. This is not a minor point in the context of the European Union, where the veto power of countries, coupled with their desire to maintain the status quo for their economies, accounts for strong inertia in the decision-making process. Such tendency toward inertia can only grow now with the accession of 10 more members in May 2004. Our result that in fact the distribution of economic activity in the crucial and quite mobile industry that is international road transport should be reassuring to those involved in the 
development of supranational policy at the EU level and potentially elsewhere as well. 


\section{References}

Allen, B. (1990) Deregulation and information costs, Transportation Journal, winter, 58-67

Allen, J. (2000) Road freight cabotage 1991-1999, Statistics in Focus, Theme 7, EurostatLuxembourg.

Arruñada, B., M. Gonzalez-Diez, and A. Fernandez, (2004), Determinants of Organizational Form: Transaction Costs and institutions in the European Trucking Industry, Industrial and Corporate Change, 13 (6), 867-882.

Athearn, F. (1989) LTL service in the west: long-term losses replace short-term gains, Transportation Research Forum, 30 (1), 98-111.

Baker, G. and T. Hubbard (2004) Contractibility and Asset Ownership: On-Board Computers and Governance in U.S. Trucking," Quarterly Journal of Economics, forthcoming.

Baker, G. and T. Hubbard (2003) Make versus buy in trucking: asset ownership, job design and information, American Economic Review, 93 (3), 551-572.

Baum, H. (1983) Possibilities and limits of regulation in transport policy, in Report of the sixty second round table of transport economics, ECMT Paris.

Bayliss and Coleman (1994) Report of the Committee of Enquiry on road freight transport in the Single European Market, Brussels, European Commission.

Bernadet, M. (1997) Le transport routier des marchandises: fonctionnement et dysfonctionnements, Paris : Economica.

Boyer, K. (1993) Deregulation of the trucking sector: specialization, concentration, entry and financial distress, Southern Economic Journal, 59 (3), 481-495.

Boylaud, O. (2000) Regulatory reform in road freight and retail distribution, OECD Economics Department working paper 255, OECD.

Burks, S. (1998) Product market segmentation in motor freight: a survival analysis of firm specialization after deregulation, mimeo, University of Minnesota, Morris.

Commission of the European Communities (2000), Report from the commission on the implementation of Regulation (EEC) 3118/93: $2^{\text {nd }}$ Report, COM, 105 final.

Degli Abbati, Carlo (1987) Transport and European integration, The European perspectives series, Office for the official publications of the European communities.

ECMT (1991) Deregulation of freight transport, Report of the eighty fourth round table on transport economics, ECMT-Paris.

ECMT (2001) Road freight transport for own account in Europe, Report of the hundred and fifth round table on transport economics, ECMT-Paris.

ECMT (2002) Regulatory reform in road freight transport, Proceedings of the international seminar, ECMT-Paris.

ECMT $(1990,1992,1994)$ Statistics in trend, ECMT-Paris.

EU (1999 and 2000) Transport in figures, statistical pocketbook, Office for the official publications of the European communities. 
EU (2001 and 2003) EU energy and transport in figures, statistical pocketbook, Office for the official publications of the European communities.

European Commission (1997) Road freight transport, The Single Market Review, Subseries II: Impact on services, $\mathbf{5}$.

European Commission (2003) Panorama of transport: Statistical overview of transport in the European Union, 2002 ed., Office for the official publications of the European communities

Felton, J. and D. Anderson (1989) Regulation and deregulation of the motor carrier industry, Iowa State University Press.

Fernandez, A., Arruñada, B. and M. Gonzalez-Diez (2000) Quasi Integration in Less-ThanTruckload Trucking, in C. Ménard (ed.) Institutions, Contracts and Organizations: Perspectives from new Institutional Economics, pp. 293-312, Edward Elgar Publishing, Cheltenham UK

Gentry, J., Semeijn, J. and D. Vellenga (1995) The future of road haulage in the new European Union - 1995 and beyond, Logistics and Transportation Review, 31(2).

Grossman, S. and O. Hart (1986) The costs and benefits of ownership: a theory of vertical and lateral integration, Journal of Political Economy, vol. 94 (4), 691-719.

Harper, D. and J. Johnson (1987) The potential consequences of deregulation of transportation revisited, Land Economics, vol. 63 (2), 137-146.

Hart, O. and J. Moore (1990) Property rights and the nature of the firm, Journal of Political Economy, 98 (6), 1119-1158.

Hubbard, T. (2001) Contractual form and market thickness in trucking, RAND Journal of Economics, 32 (2), 369-386.

Hubbard, T. (2000) The demand for monitoring technologies: the case of trucking, Quarterly Journal of Economics, 115 (2): 533-560.

Joskow, P. and N. Rose (1989) The effects of economic regulation, in R. Schmalensee and R.D.Willig (ed.) Handbook of Industrial Organization, vol. II, 1449-1506, Amsterdam: North Holland Publishing.

Klein, B., Crawford, R. and A. Alchian (1979) Vertical integration, appropriable rents and the competitive contracting process, Journal of Law and Economics, 21 (2), 297-326.

Masten, S. (1993) Transaction costs, mistakes, and performance: assessing the importance of governance, Managerial and Decision Economics, 14, 119-129.

Masten, S., Meehan, J. and E. Snyder (1991) The costs of organization, Journal of Law, Economics and Organization, 7 (1), 1-25.

McKinnon, A. (1996) Privatisation and regulation of road freight transport, second part: Deregulation review of road freight transport, ECMT seminar, Paris, Sept. 5

McKinnon, A. (1998) The abolition of quantitative controls on road freight transport: the end of an era, Transport Logistics, 1 (3), 211-223.

Moore, T. (1991) Unfinished business in motor carrier deregulation, Regulation, 14 (3) 
Nickerson and Silverman (2003) Why Aren't All TruckDrivers Owner-Operators? Asset Ownership and the Employment Relation in Interstate For-Hire Trucking, Journal of Economics and Management Strategy, 12 (1), 91-118

Oberhausen, J. and M. Smihily (2004) Trends in road freight transport 1990-2002, Statistics in focus, Theme 7, Eurostat-Luxembourg

OECD (1988) Road transport deregulation: experience, evaluation, research, Proceedings from an international conference OECD, Paris

OECD (1990) Competition policy and the deregulation of the road sector, OECD Paris

Peoples, J. and M. Peteraf (1995) "Deregulation and the Competitive Fringe: OwnerOperators in the Trucking Industry," Journal of Regulatory Economics 7, 27-42.

Peoples, J. and M. Peteraf (1999) "The Effects of Regulatory Reform on Company Drivers and Owner-Operators in the For-Hire and Private Sectors," Transportation Journal, 38, 5-17.

Pfohl, H. (1993) EC unification and the outlook for logistics, Journal of Business Logistics, 14(1), 43-79

Rakowski, J. (1994) The continuing structural transformation of the U.S. less-than-truckload motor carrier industry. Transportation Journal, Fall 1994.

Rose, N. L. (1985) The incidence of regulatory rents in the motor carrier industry, RAND Journal of Economics, 16 (3), 299-318

Rose, N. L. (1987) "Labor Rent Sharing and Regulation: Evidence from the Trucking Industry," Journal of Political Economy 95: 1146-1178.

Savy, M (1997) Freight transport policy in Europe: the union and its member states, Journal of International Association of Traffic and Safety Sciences, 21(1).

Scharf, M. and W. Smolders (1999) Own account transport of goods by road in the European Union. Final report, IRU Brussels

Whinston, M. (2003) On the transaction cost determinants of vertical integration, Journal of Law, Economics and Organization, 19 (1), 1-23

Whitelegg, J. (1988) Transport Policy in the EEC, Routeledge, London

Winston, C. (1998) U.S. industry adjustment to economic deregulation, Journal of Economic Perspectives, 12 (3), 89-110

Winston, C., T. Corsi, C. Grimm and C. Evans (1990) The economic effects of surface freight deregulation, The Brookings Institution, Washington D.C.

Ying J. and T. Keeler (1991) Pricing in a deregulated environment: the motor carrier experience, RAND Journal of Economics, 22 (2), 264-273 


\section{Appendix A}

In Europe, own-account transport was originally defined in the 1957 resolution of the ECMT (European Council of the Ministers of Transport). According to this resolution a movement of goods is to be considered transport for own account if it is performed by a natural or legal person:

- Using vehicles either owned by him or put to his exclusive disposal for internal transport movements under the conditions laid down in national laws and regulations or in bilateral agreements if it concerns international transport.

- For his own requirement and to move goods either owned by him or sold, bought, borrowed, loaned, let out on hire or hired, produced, processed or repaired by him, provided that such transport is ancillary to the main activities of the firm.

Council directive 74/149/EEC published in the OJ L 084 of 28/03/1974 extends the first Council Directive of 23 July 1962 to own-account transport. However the first directive that defines own-account transport is council directive 80/49/EEC published in OJ L 18 24/1/1980, amended by regulation 881/92. It specifies that carriages for which the following conditions arise must be exempt from any transport quota or authorization system (see the text for more on these as they apply to the for-hire segment):

- The goods transported are owned by the firm or have been sold, bought let out on hire or hired, produced, extracted, processed or repaired by the firm.

- The purpose of the journey is to carry the goods to or from the firm or to move them for its own requirements.

- The motor vehicles used are driven by employees of the firm

- The vehicles carrying the goods are owned by the firm or have been bought by it on deferred terms or hired provided that in the latter case they meet the conditions of Council Directive 84/647/EEC of December 191984 (amended by Dir. 90/398/EEC) on the use of vehicles hired without drivers for the carriage of goods by road.

- Carriage is ancillary to the overall activities of the firm. 


\section{Appendix B}

Distribution of community quotas over the period 1969 - 1984. Source: Degli Abbati (1987)

\begin{tabular}{|c|c|c|c|c|c|c|}
\hline & $\mathbf{1 9 6 9}^{\mathbf{4 1}}$ & $\mathbf{1 9 7 3}^{\mathbf{4 2}}$ & $\mathbf{1 9 7 5}^{\mathbf{4 3}^{3}}$ & $\mathbf{1 9 7 8}^{\mathbf{4 4}}$ & $\mathbf{1 9 8 0}^{\mathbf{4 5}}$ & $\mathbf{1 9 8 2}^{\mathbf{4 6}}$ \\
\hline Belgium & 161 & 191 & 265 & 318 & 413 & 434 \\
Denmark & -- & 68 & 169 & 203 & 286 & 305 \\
Germany & 286 & 321 & 427 & 512 & 689 & 727 \\
Greece & -- & -- & -- & -- & -- & 88 \\
France & 286 & 313 & 409 & 491 & 627 & 656 \\
Ireland & -- & 23 & 50 & 60 & 76 & 88 \\
Italy & 194 & 230 & 319 & 383 & 539 & 567 \\
Luxembourg & 33 & 45 & 70 & 84 & 106 & 111 \\
Netherlands & 240 & 279 & 382 & 458 & 597 & 626 \\
UK & -- & 114 & 272 & 326 & 418 & 436 \\
\hline Total & 1200 & 1584 & 2363 & 2835 & 3751 & 4038 \\
authorized & & & & & \\
\hline
\end{tabular}

Distribution of community quotas over the period 1985 - 1992

\begin{tabular}{|c|c|c|c|c|c|c|c|c|}
\hline & $\mathbf{1 9 8 5}^{\mathbf{4 7}}$ & $\mathbf{1 9 8 6}^{\mathbf{4 8}}$ & $\mathbf{1 9 8 7}^{\mathbf{4 9}}$ & $\mathbf{1 9 8 8}^{\mathbf{5 0}}$ & $\mathbf{1 9 8 9}^{\mathbf{5 0}}$ & $\mathbf{1 9 9 0}^{\mathbf{5 1}}$ & $\mathbf{1 9 9 1}^{\mathbf{5 2}}$ & $\mathbf{1 9 9 2}^{\mathbf{5 2}}$ \\
\hline Belgium & 570 & 707 & 1036 & 1488 & 2084 & 2918 & 4133 & 5787 \\
Denmark & 469 & 625 & 929 & 1444 & 2022 & 2831 & 4010 & 5614 \\
Germany & 914 & 1112 & 1735 & 2374 & 3324 & 4654 & 6986 & 9781 \\
Greece & 131 & 170 & 293 & 658 & 922 & 1291 & 1829 & 2561 \\
Spain & -- & 673 & 1014 & 1543 & 2161 & 3026 & 4286 & 6001 \\
France & 801 & 957 & 1488 & 2018 & 2826 & 3957 & 5604 & 7846 \\
Ireland & 147 & 204 & 341 & 671 & 940 & 1316 & 1865 & 2611 \\
Italy & 721 & 883 & 1424 & 2022 & 2831 & 3964 & 5614 & 7860 \\
Luxembourg & 179 & 245 & 404 & 693 & 971 & 1360 & 1926 & 2697 \\
Netherlands & 785 & 955 & 1553 & 2104 & 2946 & 4125 & 5842 & 8179 \\
Portugal & -- & 233 & 416 & 873 & 1223 & 1713 & 2427 & 3398 \\
UK & 551 & 673 & 902 & 1265 & 1771 & 2480 & 3512 & 4917 \\
\hline Total authorized & 5268 & 7437 & 11535 & 17153 & 24021 & 33635 & 48034 & 67252 \\
\hline
\end{tabular}

${ }^{41}$ Council Reg. $1018 / 68$ in OJ L 175 of $23 / 7 / 68$.

${ }^{42}$ Council Reg. 2829/72 in OJ L 298 of 31/12/72. The increase was 15\% for 1973 and 1974.

${ }^{43}$ Council Reg. 3256/74 in OJ L 349 of 28/12/74.

${ }^{44}$ Council Reg. 3024/77 in OJ L 358 of 31/12/77.

${ }^{45}$ Council Reg. 2963/79 in OJ L 336 of 29/12/79.

${ }^{46}$ Council Reg. 663/82 in OJ L 78 of 24/3/82. A $15 \%$ increase for Greece and Ireland and a $5 \%$ increase for all other member states.

${ }^{47}$ Council Reg. $3621 / 84$ in OJ L 333 of 21/12/84 p. 61

${ }^{48}$ Council Reg. $3677 / 85$ in OJ L 354 of 30/12/85

${ }^{49}$ Council Reg. $1879 / 87$ in OJ L 179 of $3 / 7 / 87$

${ }^{50}$ Council Reg. $1841 / 88$ in OJ L 163 of $30 / 6 / 88$

${ }^{51}$ Council Reg. 1053/90 in OJ L 108 of 28/4/90

${ }^{52}$ Council Reg. 3914/90 and 3915/90 in OJ L 375 of 12/1990. Council reg. 3915/90 increases the quotas allocated to all countries slightly and to Germany significantly in view of the German unification. 
Proportion of international freight transport deregulated, 1982-1992, assuming $90 \%$ is deregulated in 1992 and $100 \%$ is deregulated starting in 1993. Each cell is [\#authorizations(t) / \#authorizations(1992)] * 90

\begin{tabular}{|c|c|c|c|c|c|c|c|c|c|}
\hline & $\mathbf{1 9 8 2 - 8 4}$ & $\mathbf{1 9 8 5}$ & $\mathbf{1 9 8 6}$ & $\mathbf{1 9 8 7}$ & $\mathbf{1 9 8 8}$ & $\mathbf{1 9 8 9}$ & $\mathbf{1 9 9 0}$ & $\mathbf{1 9 9 1}$ & $\mathbf{1 9 9 2}$ \\
\hline Belgium & 6.75 & 8.86 & 11 & 16.11 & 23.14 & 32.41 & 45.38 & 64.28 & 90 \\
Denmark & 4.89 & 7.52 & 10.02 & 14.89 & 23.15 & 32.42 & 45.38 & 64.29 & 90 \\
Germany & 6.69 & 8.41 & 10.23 & 15.96 & 21.84 & 30.59 & 42.82 & 64.28 & 90 \\
Greece & 3.09 & 4.6 & 5.97 & 10.3 & 23.12 & 32.4 & 45.37 & 64.28 & 90 \\
Spain & -- & -- & 10.09 & 15.21 & 23.14 & 32.41 & 45.38 & 64.28 & 90 \\
France & 7.52 & 9.19 & 10.98 & 17.07 & 23.15 & 32.42 & 45.39 & 64.28 & 90 \\
Ireland & 3.03 & 5.07 & 7.03 & 11.75 & 23.13 & 32.4 & 45.36 & 64.29 & 90 \\
Italy & 6.49 & 8.26 & 10.11 & 16.31 & 23.15 & 32.42 & 45.39 & 64.28 & 90 \\
Luxembourg & 3.7 & 5.97 & 8.18 & 13.48 & 23.13 & 32.4 & 45.38 & 64.27 & 90 \\
Netherlands & 6.89 & 8.64 & 10.51 & 17.09 & 23.15 & 32.42 & 45.39 & 64.28 & 90 \\
Portugal & -- & -- & 6.17 & 11.02 & 23.12 & 32.39 & 45.37 & 64.28 & 90 \\
UK & 7.98 & 10.09 & 12.32 & 16.51 & 23.15 & 32.42 & 45.39 & 64.28 & 90 \\
\hline
\end{tabular}

Proportion of cabotage deregulated, 1990-1998, assuming $90 \%$ is deregulated in 1997 and $100 \%$ is deregulated starting in 1998. 0\% is deregulated prior to 1990. Each cell is [\#authorizations(t) / \#authorizations(1997)] * 90

\begin{tabular}{|c|c|c|c|c|c|c|c|c|}
\hline & $\mathbf{1 9 9 0}$ & $\mathbf{1 9 9 1}$ & $\mathbf{1 9 9 2}$ & $\mathbf{1 9 9 3}$ & $\mathbf{1 9 9 4}$ & $\mathbf{1 9 9 5}$ & $\mathbf{1 9 9 6}$ & $\mathbf{1 9 9 7}$ \\
\hline Belgium & 9.45 & 19.86 & 21.86 & 22.91 & 38.84 & 52.74 & 68.57 & 90.00 \\
Denmark & 9.45 & 19.85 & 21.85 & 22.91 & 38.82 & 52.74 & 68.58 & 90.00 \\
Germany & 9.46 & 19.87 & 21.87 & 22.92 & 38.83 & 52.75 & 68.58 & 90.00 \\
Greece & 9.44 & 19.83 & 21.86 & 22.94 & 38.78 & 52.71 & 68.54 & 90.00 \\
Spain & 9.46 & 19.86 & 21.87 & 22.92 & 38.81 & 52.73 & 68.57 & 90.00 \\
France & 9.46 & 19.87 & 21.86 & 22.91 & 38.83 & 52.75 & 68.58 & 90.00 \\
Ireland & 9.44 & 19.83 & 21.84 & 22.90 & 38.83 & 52.76 & 68.59 & 90.00 \\
Italy & 9.46 & 19.87 & 21.86 & 22.91 & 38.84 & 52.75 & 68.58 & 90.00 \\
Luxembourg & 9.45 & 19.85 & 21.84 & 22.88 & 38.77 & 52.73 & 68.56 & 90.00 \\
Netherlands & 9.46 & 19.87 & 25.51 & 22.91 & 38.82 & 52.75 & 68.58 & 90.00 \\
Austria & -- & -- & -- & -- & -- & 0.00 & 0.00 & 90.00 \\
Portugal & 9.45 & 19.84 & 21.85 & 22.91 & 38.84 & 52.75 & 68.58 & 90.00 \\
Finland & -- & -- & -- & -- & 8.70 & 52.71 & 68.55 & 90.00 \\
Sweden & -- & -- & -- & -- & 13.22 & 52.73 & 68.56 & 90.00 \\
UK & 9.45 & 19.84 & 21.84 & 22.89 & 38.81 & 52.15 & 68.57 & 90.00 \\
Liechtenstein & -- & -- & -- & -- & -- & 34.74 & 67.89 & 90.00 \\
Norway & -- & -- & -- & -- & 20.48 & 53.17 & 69.21 & 90.00 \\
Iceland & -- & -- & -- & -- & 19.57 & 50.87 & 66.52 & 90.00 \\
\hline
\end{tabular}

Distribution of cabotage quotas over the period 1990 - 1998: number of 2-month cabotage authorizations. ${ }^{53}$

\footnotetext{
${ }^{53}$ Commission of the European Communities (2000)
} 


\begin{tabular}{|c|c|c|c|c|c|c|c|c|c|}
\hline & $1990^{54}$ & $1991^{55}$ & 1992 & 1993 & $1994^{56,57}$ & $1995^{58}$ & $1996^{6}$ & 1997 & $1998^{59}$ \\
\hline Belgium & 661 & 1388.5 & 1528.5 & 1602 & 2715 & 3687 & 4794 & 6292 & 4090 \\
\hline Denmark & 641 & 1346.5 & 1482.5 & 1554 & 2634 & 3578 & 4653 & 6106 & 3969 \\
\hline Germany & 1085 & 2278.5 & 2507.5 & 2628 & 4452 & 6047 & 7862 & 10318 & 6707 \\
\hline Greece & 292 & 613.5 & 676.5 & 710 & 1200 & 1631 & 2121 & 2785 & 1811 \\
\hline Spain & 685.5 & 1440 & 1585.5 & 1662 & 2814 & 3823 & 4971 & 6525 & 4243 \\
\hline France & 896.5 & 1883 & 2072.5 & 2172 & 3681 & 5000 & 6501 & 8531 & 5546 \\
\hline Ireland & 297.5 & 625 & 688.5 & 722 & 1224 & 1663 & 2162 & 2837 & 1845 \\
\hline Italy & 897.5 & 1885 & 2074.5 & 2174 & 3685 & 5005 & 6507 & 8539 & 5552 \\
\hline Luxembourg & 308 & 647 & 712 & 746 & 1264 & 1719 & 2235 & 2934 & 1909 \\
\hline Netherlands & 934.5 & 1962.5 & 2519 & 2262 & 3834 & 5209 & 6773 & 8888 & 5778 \\
\hline Austria & -- & -- & -- & -- & -- & 0 & 0 & 4256 & 2767 \\
\hline Portugal & 388.5 & 816 & 898.5 & 942 & 1597 & 2169 & 2820 & 3701 & 2406 \\
\hline Finland & -- & -- & -- & -- & 296 & 1794 & 2333 & 3063 & 1992 \\
\hline Sweden & -- & -- & -- & -- & 590 & 2354 & 3061 & 4018 & 2613 \\
\hline UK & 562 & 1180.5 & 1299.5 & 1362 & 2309 & 3103 & 4080 & 5355 & 3482 \\
\hline Liechtenstein & -- & -- & -- & -- & -- & 22 & 43 & 57 & 37 \\
\hline Norway & -- & -- & -- & -- & 198 & 514 & 669 & 870 & 567 \\
\hline Iceland & -- & -- & -- & -- & 5 & 13 & 17 & 23 & 15 \\
\hline $\begin{array}{c}\text { Total } \\
\text { authorized }\end{array}$ & 7649 & 16066 & 17685 & 18536 & 32498 & 47366 & 61602 & 85098 & 55329 \\
\hline
\end{tabular}

\footnotetext{
${ }^{54}$ Council Reg. 4059/89 in OJ L 390 of 30/12/89, which entered into effect on July 11990 . This regulation also specified that the quota should increase annually starting from July 1 1991, In 1991, 1992 and 1993 the number of authorizations increased by $10 \%$. The cabotage increases were allocated linearly.

${ }^{55}$ The increase in the quota on January 1991 accounted for the unification of Germany. See Council Reg. 296/91 in OJ L 36 of 08/02/91.

${ }^{56}$ Council Reg. 3118/93 in OJ L 279 of 12/11/93. Regulation 792/94 (in OJ L 92 of 9/4/94) introduced the possibility of cabotage for own-account operations, valid from 1/1/1994, that is retroactively. Council Reg. 3118/93 was amended by Council Reg. 3315/94 published in OJ L 350. The latter regulation accounts for the enlargement of the Community to the whole EEA area (except Austria and Switzerland) starting in July 1994. See following note.

${ }^{57}$ The cabotage regime was extended to the whole EEA area (except Austria and Switzerland). See Annex 11 of the Decision of the EEA Joint Committee n. 7/94 published in the OJ L 160 of 21/3/94.

${ }^{58}$ Increases in quotas following enlargement of the European Economic Area. The Decision of the EEA Joint Committee n. 60/95 published in the OJ L 251 of 3/10/96 defines the allocation of additional cabotage permits.

${ }^{59}$ Cabotage authorizations for 1998 are for the period January 1 to June 30 only. Starting on July 1, 1998 cabotage authorizations are no longer required.
} 


\section{Appendix C: Brief history of the enlargement of the EU}

1957 - The EU (still EEC at this point) is established by the Treaty of Rome. The six founding members are Belgium, France, Germany, Italy, Luxembourg and the Netherlands.

1973 - Denmark, Ireland and the UK join.

1981 - Greece joins.

1986 - Spain and Portugal join

1990 - Eastern Germany joins through the German reunification process

1995 - Finland, Sweden and Austria officially join. Now there are 15 members in the EU. 
Figure 1

Total international road ton-kms transported 1982 - 2002

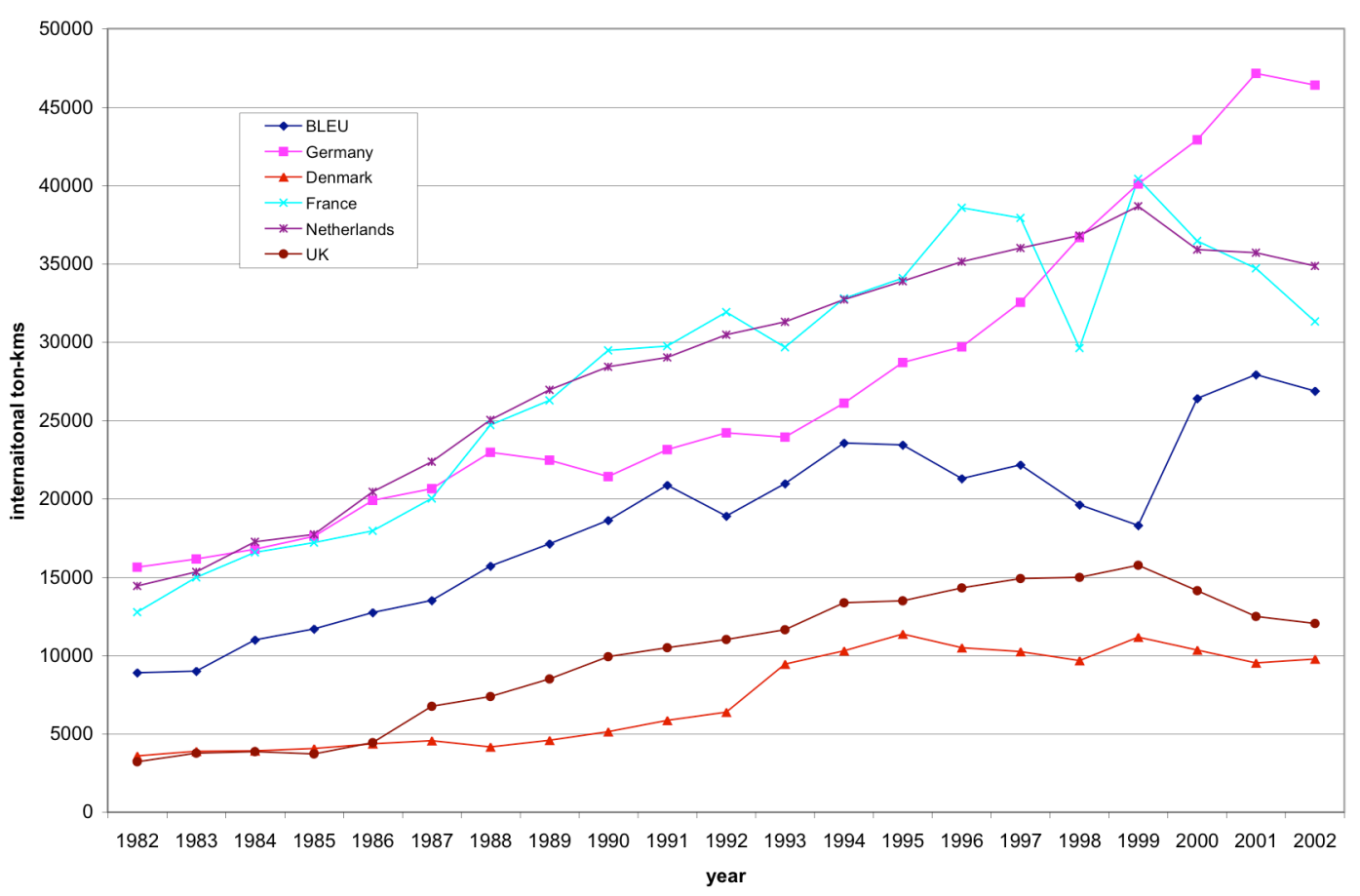

Figure 2

Percent for hire (tkm for hire /total tkm)

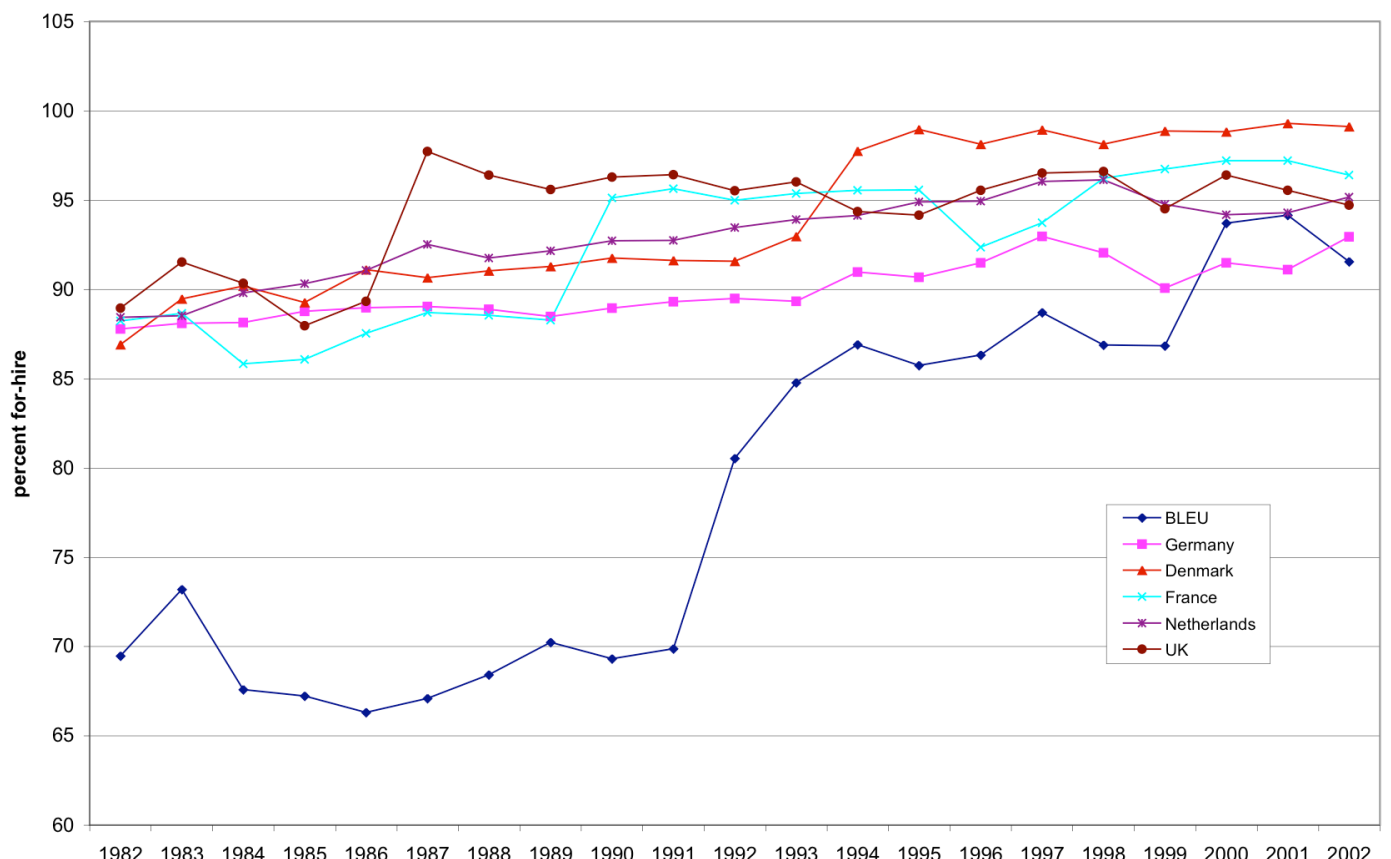

year 


\section{Figure 3}

Share of international road freight transport

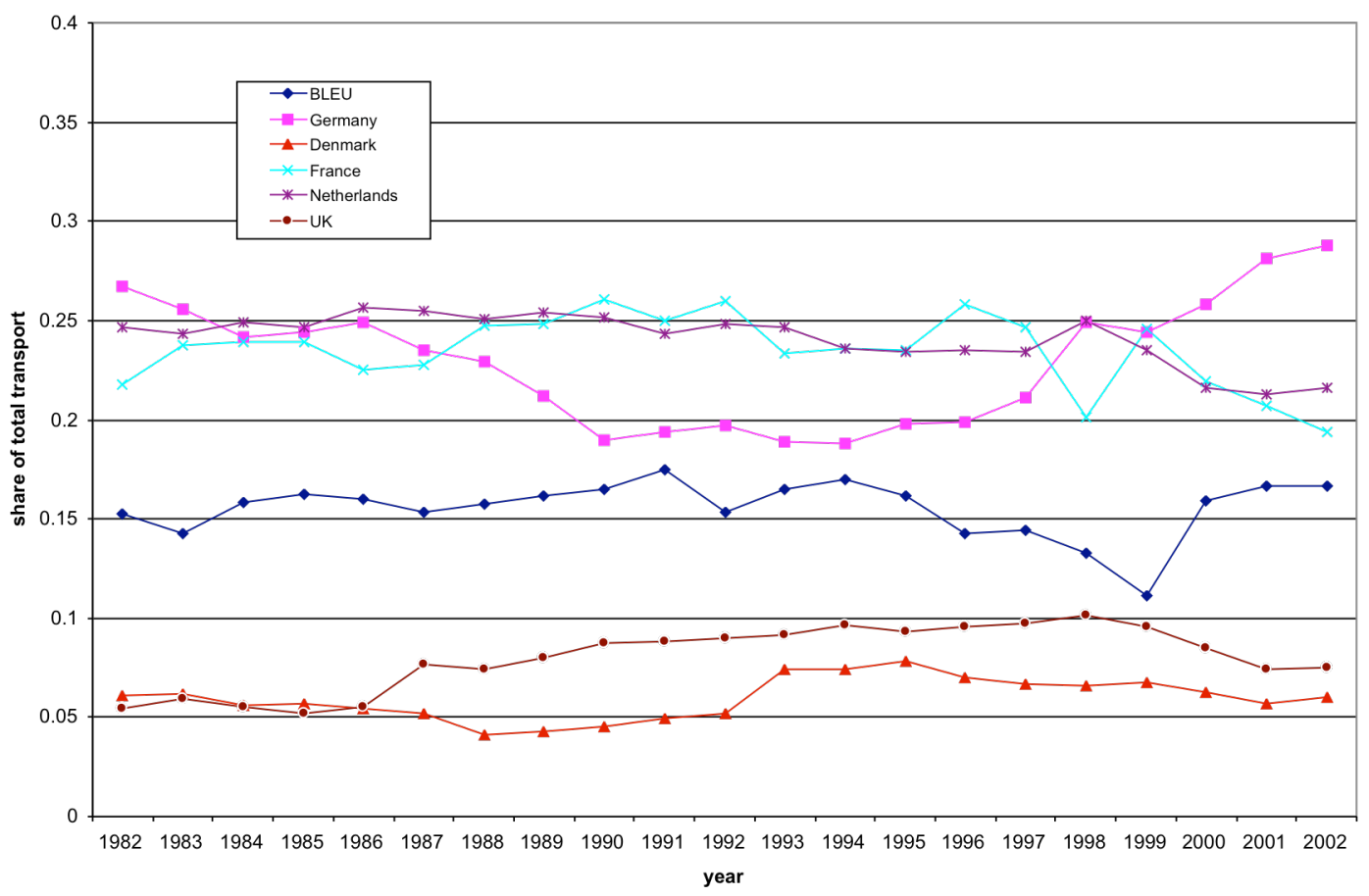

Figure 4

Share of total international transport by road/ share of total gdp, 6 countries

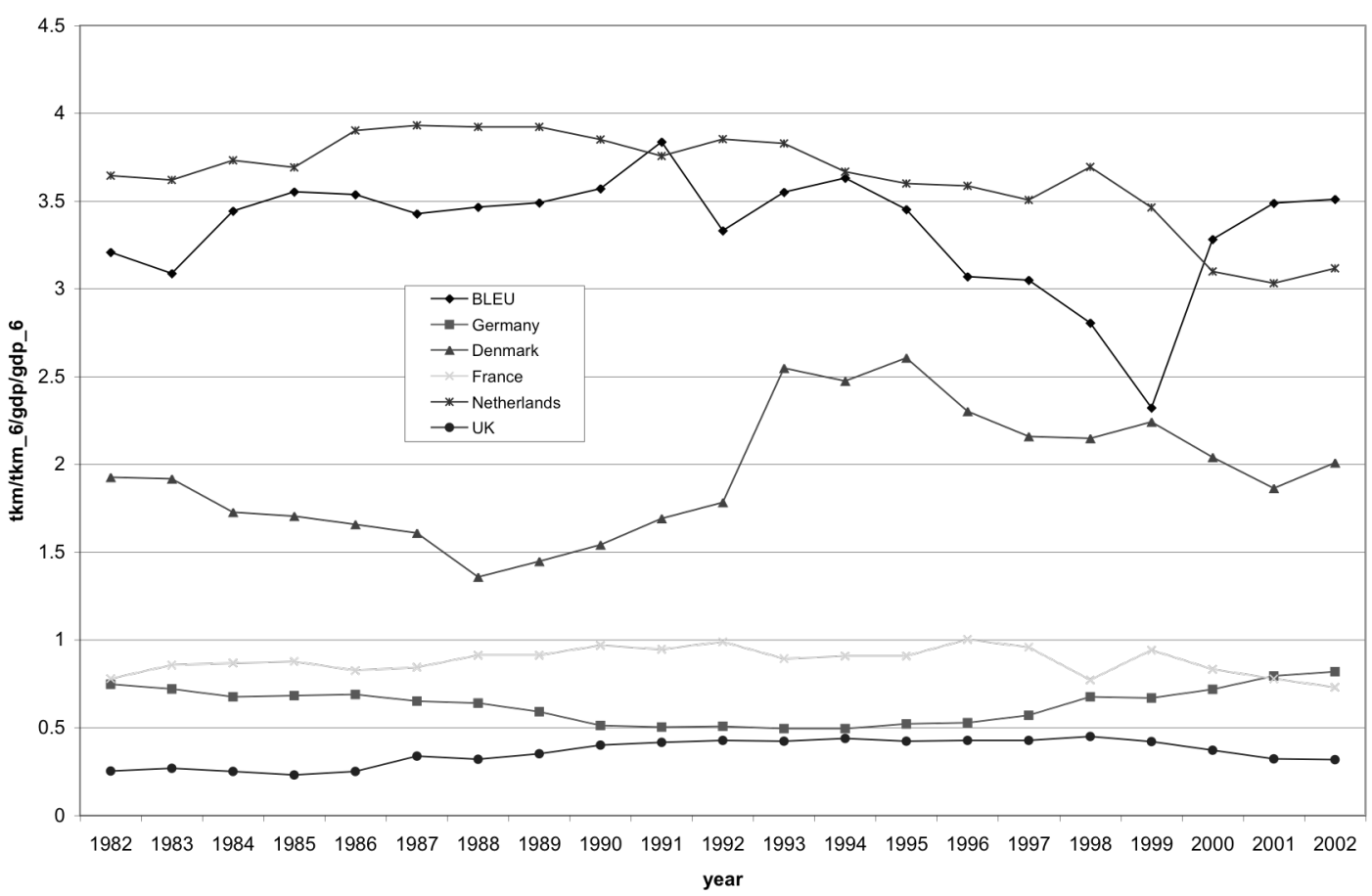




\section{Figure 5}

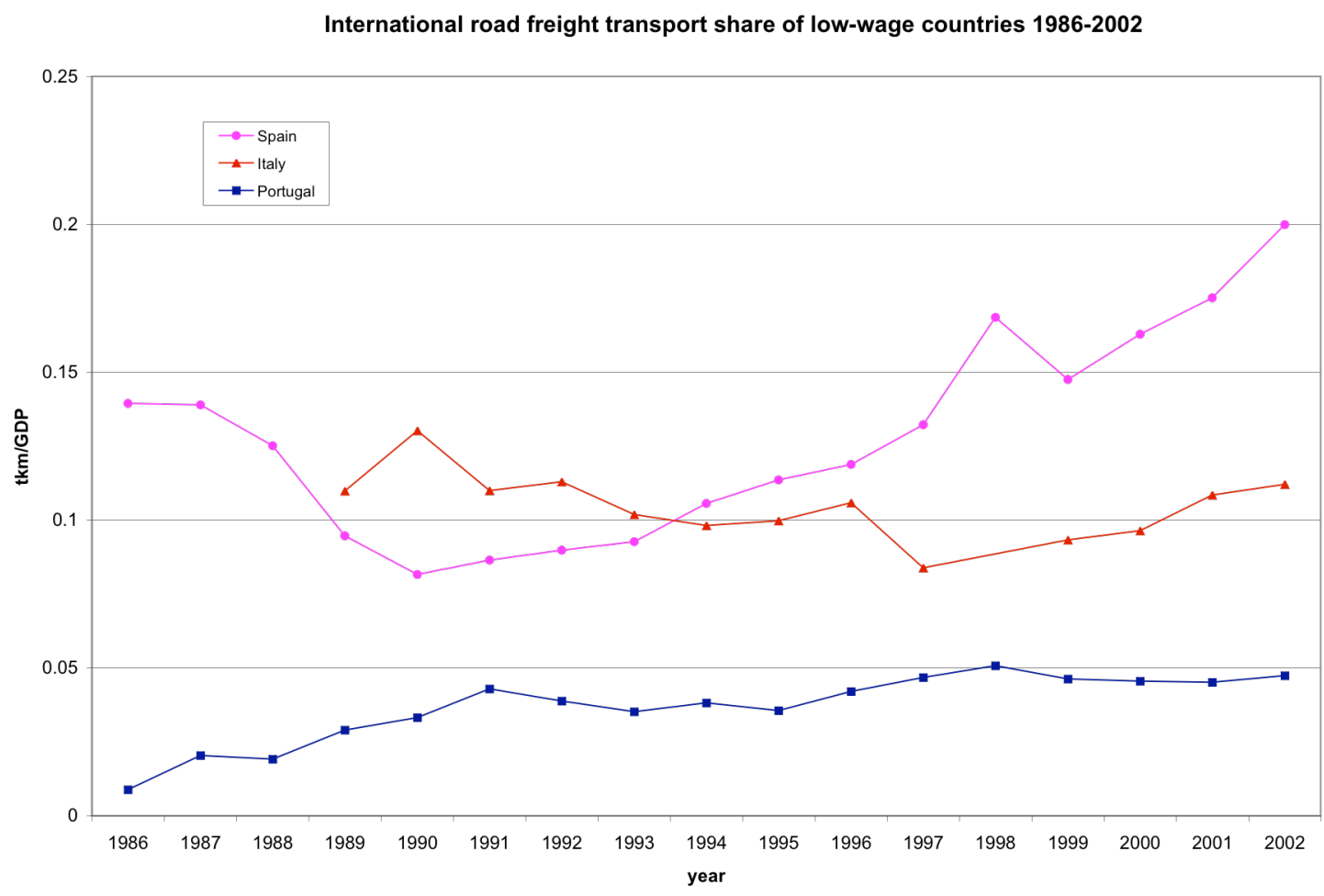

